\title{
Harika (Şazi Sirel) Lifij; Sanatçı Kişiliği ve Resimleri Üzerine
}

\author{
Harika (Şazi Sirel) Lifij; On Her Personality as an Artist and Her Paintings
}

\section{İlkay Canan Okkalı* $\odot$}

\section{Öz}

Harika Hanım'ın (Şazi Sirel Lifij) eğitim aldığı II. Meşrutiyet dönemi Osmanlı'da siyasi yapının değişimi ile yavaş yavaş kadınların kamusal alana katıldığı ve görünürlük kazandığı yıllara denk gelir. II. Meşrutiyetin ilanı ile başlayan süreç aynı zamanda resim alanında eğitim alan kadınların varlığı açısından da önemlidir. Harika Hanım da ilk resim eğitimini Müfide Kadri'den alır. 1918'de açılan Viyana Sergisi'ne seçilen iki kadın sanatçıdan biridir. Viyana Sergisi, Avrupa'da Türk ressamları tarafından açılan ilk sergi olması bakımından önemlidir. Bu sergiye bir kadın sanatçı olarak resimlerinin seçilmiş olması Harika Hanım'ın sanatı ve kariyeri açısından önemli bir hadisedir. Harika Hanım genellikle manzara resimleri, otoportre ve mitolojik resimler yapar. Manzara ve poşadlarında renkler daha yumuşak ve şiirsel bir ifade kazanmıştır. Harika Hanım'ın resimlerinde genellikle tarih bulunmamasından dolayı anılarında anlattığı mekânlar ve kullandığı renkler göz önünde bulundurularak bir kronoloji oluşturulmaya çalışılmıştır. 1957 yılına kadar resim yapmaya devam eden sanatçı kendi resimlerini koruma konusunda Avni Lifij'in resimlerini korumaktaki gibi titiz davranmamıştır. Günümüze gelen elliye yakın resmi ailesinde ve özel koleksiyonlarda bulunmaktadır. Çalışmamız sırasında ortaya çıkan Fatih Cami/Ramazan Gecesi resmi gibi başka çalışmaları da zaman içerisinde ortaya çıkabilir. Bu çalışmada, Harika Hanım'ın resimleri ve katıldığı sergiler, hakkındaki eleştiri yazıları ile dönemi içerisindeki yeri incelenmiştir.

\section{Anahtar Kelimeler}

Harika Lifij, Kadın ressam, Türk resmi, Meşrutiyet kadını

\begin{abstract}
Harika Lifij (Şazi Sirel Lifij) got her education during the Second Constitutional Era (1908). This was a time when the political structure in the Ottoman Empire changed and women became visible and gradually started participating in the public sphere. The process that started with the constitutional monarchy is important in that women could get an education in the field of painting. And Harika got her first painting lessons from Müfide Kadri. Harika is one of the two female artists chosen for the 1918 Exhibition of Vienna. The Vienna Exhibition was notable in terms of being the first one opened by Turkish painters in Europe. As a female artist, the fact that Harika's paintings were chosen for the exhibition is important for her art and career. She generally painted landscapes, self-portraits and mythological scenes. She painted landscapes and made pochades. In these paintings the colours are subtler and they have a poetic expression. Since she did not date her paintings in general, the chronology is based on the locations she mentioned in her diary and the colours she used. The artist, who carried on painting until 1957, was not as keen on protecting her own paintings as she was on protecting Avni Lifij's. Approximately 50 of her works are extant and they are either in family or private collections. Like the Fatih Mosque/Ramadan Night painting that we attributed to her during this study, other works of hers might show up in the course of time. In this work, the paintings of Harika Lifij and the reviews of the exhibitions that she participated in are studied so as to define her place in that era.
\end{abstract}

\section{Keywords}

Harika Lifij, female painter, Turkish painting, Constitutional monarchy woman

* Sorumlu Yazar: İlkay Canan Okkalı (Dr. Öğr. Üyesi), Trabzon Üniversitesi, Güzel Sanatlar Fakültesi, Resim Bölümü, Trabzon, Türkiye. E-posta: icanikli@gmail.com ORCID: 0000-0003-1817-4060

Atıf: Okkali, Ilkay Canan. “Harika (Şazi Sirel) Lifij; Sanatçı Kişiliği ve Resimleri Üzerine.” Art-Sanat, 14(2020): 273-296. https://doi.org/10.26650/artsanat.2020.14.0011 


\section{Extended Summary}

Harika Lifij was born on 7 April 1896 in Amasya. In the years when Harika Lifij was born, the state was going through a process of educational reforms and new regulations as part of its efforts to survive, however the degree of participation of girls in education was still a matter of discussion. Since there were no schools for girls, she attended a boys' primary school in Amasya. She came by this opportunity for education by virtue of her father's position as the head of the National Education Board. Harika Lifij came to Istanbul in 1905 with her family. She received training to become a teacher in Dar-ül Muallimat-1 Aliyye (Teacher Education School for Girls) in Istanbul. Müfide Kadri (1889-1912), one of the first women painters, taught her painting. Müfide Kadri appreciated Harika Lifij's paintings and advised her not to give up painting. Halide Edib Adivar (1882-1964), who supported the Constitutional Monarchy project specifically with her early novels, was among her teachers. She graduated from school in 1911 but did not start teaching there right away. During this period, she travelled with her aunt and painted freely. In 1914, she was appointed to one of the new Numune schools as an art teacher. She taught painting in many schools for girls and high schools. In 1920, she started teaching in Istanbul Dar-ül Muallimat (Girls' Teacher School), from where she graduated. While teaching, she also followed the contemporary painting exhibitions. In 1917, she met Avni Lifij, who at the time was a juror in the Exhibition of Vienna. For this exhibition, Harika made a mythological painting called İlahlar Eğleniyor (Deities are Amused). Meanwhile she completed another painting called Ahenk (Harmony).

Harika Lifij started participating in the significant exhibitions of the period. She participated in the $1^{\text {st }}$ Galatasaray Exhibition in 1916 and the $2^{\text {nd }}$ Galatasaray Exhibition in 1917, held at İstanbul Beyoğlu Galatasaraylılar Dormitory, War Paintings and Others/The Şişli Workshop Painting Exhibition in the years 1917-1918 (December-January), and the Exhibition of Vienna in 1918 at Vienna University. Harika attended the first painting exhibition of the Republican era in the Turkish Hearth building on 19 October 1923 in Ankara. Her works in the First Ankara Painting Exhibition were highly praised by the critics.

She also attended a Painting Workshop where Mr. Muazzez held classes. She attended some classes in İnas Sanayi-i Nefise School as a guest student. She closely followed her teacher Halide Edib holding meetings to protest the invasion of Istanbul and mobilising the people for liberation and to save the country. With the passing of time, Harika would become a versatile Turkish woman of the Republican era, closely following the political events of the period. The influence of the training Harika Lifij received can be seen in the progress of her style. One of her early teachers, Müfide Kadri, was an artist representing the first generation of Turkish female painters. She learned the significance of figures and colours from Müfide Kadri and the impres- 
sionist technique from Avni Lifij; however, a more classical style can be observed in her own paintings. In her landscape paintings it can be seen that she depicted various parts of Istanbul and especially Yeşilköy. She worked with Avni Lifij in nature. During these trips, she got information from Avni Lifij to improve her painting technique. Painting was the common interest of Avni Lifij and Harika. Although not many of her paintings are known in the present day, from the paintings obtained, it can be understood that Harika Lifij liked to paint mythological themes. It can be observed that she preferred to use nature sketches in the background of the mythological subject. In her self-portrait, with a realistic approach, she depicted herself with a serious expression. Among her strong social-psychological stance with her posture and facial expression, it is significant as a documentary of her time. This painting is also an illustration of her western identity as a female artist in the beginning of the $20^{\text {th }}$ century. When she was uncertain about colour, she drew the pattern on another paper and tried to experiment with various colours on the pattern. After Avni Lifij's death on 2 June 1927, she devoted her life to protecting the art and the rights of Avni Lifij. In this regard, she organised an extensive retrospective exhibition of Avni Lifij's works.

To date, many studies have been conducted on Turkish female painters by many researchers. Among those, there are no studies that examine Harika Lifij by herself. Particularly at the stage of building up her own language of painting, she separates from the other female painters of her time with her mythological subjects. The artist writes in her memoirs that she continued painting in form of sketching until 1957. After that, she completely stopped painting because of the difficulties in transferring the paintings, but she continued teaching. In 1951, at the age of 55, she retired from teaching, which she passionately had done for thirty-seven years. In her late years, she wrote her memoirs in various art magazines, such as Sanat Çevresi, Hayat Tarih ve Edebiyat, and Ankara Sanat. These memoirs are mostly about the formation of Avni Lifij's paintings and her reminiscences with Avni Lifij. This study examines the identity, biography and samples from the paintings of Harika Lifij who lived in Istanbul in the $20^{\text {th }}$ century, and who was one of the most significant female painters and art teachers of her era. 


\section{Giriş}

Harika Hanım (Şazi Sirel Lifij [1896-1991])1, Doktor Seyit Ahmetzade İbrahim Şazi Bey (1858?-1938)² ile Yennevveva'nın (?-1938) kızı, heykeltıraş Ali Nijat Sirel'in ${ }^{3}$ ablası, Avni Lifij' in (1886-1927) eşidir. İstanbul Dar-ül Muallimat-1 Aliyye'de (Kız Öğretmen Okulu) öğretmen olmak için eğitim alarak mezun olur. Resim dersini ilk kadın ressamlardan olan Müfide Kadri'den (1889-1912) alır. 1916'dan itibaren dönemin önemli sergilerine katılmaya başlar. Viyana Üniversitesi'nde 1918'de açılan Viyana Sergisi'ne yirmi sanatçı ile birlikte katılır. 1920'de mezun olduğu İstanbul Dar-ül Muallimat'ında resim öğretmenliğine başlar. Ahmet Kamil Gören'e göre Harika Hanım (Sirel Lifij) Türk resim sanatı tarihinde yaklaşık 1880-1897 yılları arasında doğan ve yaklaşık 1910-1930 yılları arasında etkin olan sanatçıların bulunduğu Dördüncü Kuşak içinde yer alır. ${ }^{4}$ Döneminin önemli sergilerinde yer alan Harika Hanım, 1957’ye kadar etüt türünde resim çalışmalarına devam eder.

$\mathrm{Bu}$ çalışma, betimsel modele dayalı nitel bir araştırmadır. Araştırmada literatür taraması yapılmış, Harika Hanım'ın anıları, temel nitelikli sanat tarihi kitapları ve konuyla ilgili makale ve tezler incelenerek veri toplanmıştır. Çalışmanın ilk bölümde yaşadığı dönemdeki kadın hareketi ve İnas Sanayi-i Nefise Mektebi'nin açılması ile kadın ressamların yetişmesi ve eğitim hayatı üzerinde durulmuş, ikinci bölümde Harika Hanım'ın sanatsal gelişimi ve yaşamındaki önemli gelişmeler incelenmiş; görsellerle analiz edilmiştir. Son bölümde Harika Hanım'ın katıldığı sergiler ve hakkındaki eleştiri yazıları değerlendirilmiştir.

1 Harika Hanım evlenene kadar sergilere Şazi Sirel soyadıyla veya Harika Hanım olarak katılmıştır. 1919'da Avni Lifij'le evlendikten sonra Harika Lifij adını kullanır. Makalede soyadı kullanımında bu kronoloji takip edilmiştir.

2 Harika Hanım anılarında babasını 1938 yılında, annesini de babasından 3 ay sonra kaybettiğini yazar. 18 Şubat 1938 tarihli $A$ kşam gazetesinde Doktor İbrahim Şazi Sirel'in 17 Şubat'ta 80 yaşında vefat ettiği yazmaktadır. Bu habere göre babası 1858 doğumludur. 11 Haziran 1938 tarihli Akşam gazetesinde Doktor İbrahim Şazi Sirel'in eşi Bayan Y. Şazi Sirel'in 9 Haziran'da vefat ettiği belirtilmektedir. Bkz. Harika Sirel Lifij' in Yaşamı, Prof. Şazi Sirel-Ayten Sirel Arşivi, 33.

3 Türk heykel sanatının önemli isimlerinden heykeltıraş Ali Nijat Sirel (1897-1959) İbrahim Şazi Bey ve Yennevveva'nın çocukları olarak ablası Harika gibi Amasya'da doğar. İstanbul Sultanisi’nde gördüğü eğitim ardından, Ali Nijat, 1915 yılında heykel eğitimi için Almanya’ya gönderilir. Münih Güzel Sanatlar Akademisi'nde eğitim gören Sirel, Prof. Kahn'ın (Hahn) atölyesinde çalıșır. Kısa süre bağımsız çalışan sanatçı, 1922'de yurda döner ve ardından İzmir Lisesi'nde resim öğretmenliğine başlar. Sirel, Vefa ve Gaziosmanpaşa okullarında da öğretmenlik yapar. Çalışmaları için şu makalelere bakılabilir: Günsel Renda, "Osmanlılarda Heykel”, Sanat Dünyamız 82 (Kış 2002), 138-145; Derya Uzun Aydın, "Cumhuriyet Dönemine Işık Tutan İki Heykeltıraş; Mahir Tomruk ve Ali Nijat Sirel,” İstanbul Sosyal Bilimler Dergisi 3 (2013), 1-17. erişim 27 Nisan 2020. http://www.istjss.org/resim/2013_spring_3_1.pdf. Diğer kardeşlerinin isimleri Enver Şazi Sirel, Nihat Sirel, Bedi Şazi Sirel’dir. Henüz küçük bir kız çocuğu iken ablası Belkıs vefat eder ve Harika bundan çok etkilenir.

4 Ahmet Kamil Gören'e göre, Ali Sami Boyar (1880-1967), Mehmet Ruhi (1880-1931), Nazmi Ziya (18811937), İbrahim Çallı (1882-1960), Hikmet Onat (1882-1977), Feyhaman Duran (1886-1970), Avni Lifij (1886-1927), Namık İsmail (1892-1935)'den oluşan ve Türk resim sanatında "1914 Kuşağı" olarak tanımladığımız sanatçılar ile İzzet Ziya Bey (1880-1934), Ali Cemal Ben'im (Beyrutlu) (1881-1939), Ali Rıza Bayezit (Bayazıt) (1885-1964), Hayri Çizel (1891-1950) ve yine aynı sanat ortamını paylaşan Celile Hikmet (1883-1956), Mihri Hanım (1886-1954), Harika Şazi (Sirel) gibi sanatçılar Dördüncü Kuşak olarak adlandırılır. Bkz. Ahmet Kamil Gören, "Kısa Yașamının Büyük Mirasıyla Avni Lifij," Avni Lifij Cağının Yenisi (İstanbul: Sabancı Üniversitesi Sakıp Sabancı Müzesi Yayını, 2019), 33. 


\section{Harika Lifij'in Eğitim Hayatı ve II. Meşrutiyet Döneminde Sanat Eğitimi}

Harika Hanım, 7 Nisan 1896'da Amasya'da dünyaya geldiğinde, devlet ayakta kalmak için eğitim reformları yapma ve yeni düzenlemeler getirme çabası içindedir ancak aynı zamanda kız çocuklarının eğitime ne kadar dâhil edileceğinin de tartış1dığı bir dönemdir. Harika, gönderileceği bir kız okulunun olmadığı başkentten uzak Amasya'da bir erkek ilkokulunda eğitim hayatına başlar. Edindiği bu eğitim şansı babası İbrahim Şazi Bey'in Milli Eğitim Kurulu başkanı olmasından kaynaklanır. Ailesi ile birlikte 1905 yılında İstanbul'a gelir. Aynı yıl İnas Sanayi-i Nefise Mektebi öncesinde kızların resim eğitimi alabildikleri tek kurum olan İstanbul Dar-ül Muallimât-1 Âliyye'de öğrenci olur. ${ }^{5}$

Tanzimat sonrasındaki yenileşme hareketiyle birlikte eğitim alanında bazı yenilikler gerçekleşir ve bu durum kadınları da etkiler. 1862 'de ilk kız rüştiyesinin ve 1869 'da kızlar için zorunlu sıbyan mekteplerinin açılması, 1870'de ilk kadın müdüre atanması ve aynı yıl Dar-ül Muallimât-1 Âliyye'nin açılması önemli adımlardır. 20. yüzyıl Osmanlı modernleşmesi pek çok alanda olduğu gibi kadın haklarının ele alınmasında da etkili olur. Kadın hareketinin Osmanlı Devleti'ndeki ilk temsilcileri tıpkı Avrupa'da olduğu gibi ileri gelen ailelerin çocuklarıdır. Bunlar daha çok elit, üst düzey ailelerden gelen konak eğitimi almış paşa kızlarıdır. Aynı zamanda basın ve cemiyet hayatında kadının görünürlüğü de artar. $^{6}$

Harika, 10 Temmuz 1908'de II. Meşrutiyet ilan edildiğinde 7. sınıf öğrencisidir. Babası İbrahim Şazi Bey Meşrutiyet'i destekleyenler arasındadır. ${ }^{7}$ II. Meşrutiyet döneminde yapılan düzenlemelerle Osmanlı'da eğitim, hukuk, ekonomi, toplumsal yaşam her yönüyle değişmeye başlar ve gelişen özgürlük ortamı resim sanatını da olumlu anlamda etkiler. Kentli aydın kadınlar arasında öğretmen, memur, yazar, şair ve ressam gibi çeşitli meslek gruplarından kadınların sayısı zaman içinde artar. ${ }^{8}$ Harika Hanım bu ortam içerisinde genç bir Meşrutiyet kadını olarak yetişir. 1909'da 8. sınıfa devam ederken resim derslerini ilk kadın ressamlardan biri olan Müfide Kadri'den alır. ${ }^{9}$ Osmanlı Ressamlar Cemiyeti'ne üye olan Müfide Kadri ve Mihri Hanım'ın II. Meşrutiyet

5 Çoğu kaynakta doğum tarihi 1890 bazen de 1895 olarak geçen Harika Hanım anılarında 7 Nisan 1896 doğumlu olduğunu ve 1981 yılındaki makalesinde de 85 yaşında olduğunu yazar. Makalede bu referanslar göz önünde bulundurularak doğum tarihi 1896 olarak alınmıştır. Harika Lifij' in hayatı ve kişiliği için bkz. Harika Sirel Lifij' in Yaşamı, Prof. Şazi Sirel-Ayten Sirel Arşivi, 1, 3, 4.

6 Serpil Çakır, Osmanlı Kadın Hareketi (İstanbul: Metis Yayınları, 1996), 108-109'dan aktaran Ümüt Akagündüz, II. Meşrutiyet Döneminde Kadın Olmak (İstanbul: Yeni İnsan Yayınevi, 2015), 194-195.

7 Harika Sirel Lifij' in Yaşamı, Prof. Şazi Sirel-Ayten Sirel Arşivi, 5, 6.

8 İlkay Canan Okkalı, "II. Meşrutiyet Dönemi Resim Sanatında Nesne ve Özne Olarak Kadın," Art Sanat 11 (Ocak 2019), 52. erişim 27 Nisan 2020, https://doi.org./10.26650/artsanat.2019.11.0003; Taha Toros, Illk Kadın Ressamlarımız (İstanbul: Akbank Yayınları, 1988), 9.

9 Şehremaneti mümeyyizlerinden Kadri Bey'in evlatlık kızı olan Müfide Kadri, zengin bir yaşam içinde Batılı tarzda büyümüş, Osman Hamdi'den ve Profesör Valeri'den resim dersleri almış, bu sırada müzik bilgisini de geliştirmiş bir ressamdır. Malik Aksel, Sanat ve Folklor, haz. Beşir Ayvazoğlu (İstanbul: Kapı Yayınları 2011), 52-53. 
döneminde kadının toplum içinde sanatsal etkinliğini başlatma yolunda büyük etkisi olur. ${ }^{10}$ Müfide Kadri'nin Dar-ül Muallimât-1 Âliyye'de öğrencisi olan Harika Hanım, Müfide'nin öğrenciler için natürmortlar düzenlediği ve onları doğadan çalışmaya teşvik ettiğinden bahseder. ${ }^{11}$ Müfide Kadri'nin resimleri, Watteau'dan Corot'ya kadar pek çok batılı ressamı etüt ettiğini gösteren çalışmalardır. ${ }^{12}$ Müfide Kadri, Harika'nın resmini beğenir, resim yapmaya devam etmesini tavsiye eder. Resim konusunda teşvik edilmesi böyle başlar ve sonrasında da takdirler ve ödüllerle devam eder. Çırağan Sarayı'nın yanışı onu etkiler, bu konuda bir çalışmasıyla ödül alır. 1911 yılında babası için yaptığı resimle birincilik kazanır. ${ }^{13} \mathrm{Bu}$ çalışmalarla ilgili bilgiye ulaşılamamıştır.

Öğretmenleri arasında özellikle ilk dönem romanlarıyla Meşrutiyet projesinin destekçisi Halide Edib Adıvar (1882-1964) da bulunur. Harika Hanım anılarında Halide Edib'in İstanbul'un işgali sırasında Fatih'te ve Sultanahmet'te mitingler düzenlediğinden bahseder. ${ }^{14}$ Her hafta düzenlediği konferanslarla okula yenilik getiren dönemin kadın hareketinin öncüsünden dersler almak Harika'nın eğitiminde ve karakterinin gelişiminde önemli olur.

II. Meşrutiyet ile göreli özgürlük ortamından kadınlar da paylarını alır ve bu ortamdan kamusal alana daha çok çıkabilmek için yararlanır. 19. yüzyılın ikinci yarısında Osmanlı'da başlayan ve kadınları da içeren eğitim hamlesi sayesinde kız okulları ilk mezunlarını verir, böylece okumuş ve aydın kadınların sayısında önemli bir artış meydana gelir. Daha önemlisi kadınlar örgütlü hak mücadelesine girerler; birbiri ardınca kadın dernekleri kurulur. Balkan Savaşları'nın, sonra da I. Dünya Savaşı'nın patlak vermesiyle giderek artan sayıda kadın çalışma hayatına girer. ${ }^{15}$ II. Meşrutiyet'in ilanından sonra kadın eğitimi konusunda bir gelişme olarak İnas Sanayi-i Nefise Mektebi kurulur ve ilk öğrencilerini Ekim 1914'te (Halil Ethem'e göre Kasım ayında) alır. ${ }^{16}$ Okulun kuruluş nedenlerinin altında "kadın eşitliği, kadın özgürlüğü, kadın hakları" gibi dönem için yeni kavramlara ilişkin düşünceler yatar. ${ }^{17}$ Mihri Hanım'ın (18861954), İnas Sanayi-i Nefise Mektebi'nin kurulmasında önemli katkıları olur. ${ }^{18}$ Okulda

10 Canan Beykal, "Yeni Kadın ve İnas Sanayi-i Nefise Mektebi," Boyut 16 (1983), 7.

11 Burcu Pelvanoğlu, "Kadın, Eğitim, Sanat," Hayal ve Hakikat: Türkiye’den Modern ve Çağdaş Kadın Sanatçllar/Dream and Reality: Modern and Contemporary Women Artists from Turkey, ed. Esin Eşkinat, (İstanbul: İstanbul Modern Sanat Müzesi Yayınları, 2011), 45, 46.

12 Burcu Pelvanoğlu, Hale Asaf-Türk Resim Sanatında Bir Dönüm Noktası (İstanbul YKY: 2007), 23, 24.

13 Harika Sirel Lifij' in Yaşamı, Prof. Şazi Sirel-Ayten Sirel Arşivi, 7.

14 Harika Sirel Lifij' in Yaşamı, Prof. Şazi Sirel-Ayten Sirel Arşivi, 9, 18.

15 Fatmagül Berktay, "Hayal ve Hakikat ya da Hayalin Hakikatine Bitmeyen Yolculuk," Hayal ve Hakikat: Türkiye'den Modern ve Çağdaş Kadın Sanatçılar/Dream and Reality: Modern and Contemporary Women Artists from Turkey, ed. Esin Eşkinat (İstanbul: Modern Sanat Müzesi, 2011), 32.

16 Ahmet Kamil Gören, "Türkiye'de Güzel Sanatlar Okulları: 2, İnas Sanayi-i Nefise Mektebi, Kadın Ressamlar, Özel Resim Atölyesi ve Resim Kursları,” Türkiyemiz Kültür ve Sanat Dergisi 82 (1997), 15.

17 Zeynep Yasa Yaman, "İnas Sanayi-i Nefise Mektebi Âlisi," Dünden Bugüne İstanbul Ansiklopedisi, c. IV (İstanbul: İletişim Yayınları, 1994), 170; Beykal, "Yeni Kadın ve İnas Sanayi-i Nefise Mektebi," 6-13.

18 Açba ailesine mensup olan Mihri, ilk evliliğini Müşfik Bey (İnegöllü) ile yapar. Müşfik 2 yıl evli kaldığı kişinin soyadıdır. Nazan Azeri, "Batılılaşma Hareketleri İçinde Kadın Ressamlar" (Yüksek Lisans Tezi, 
1919 yılına kadar çalışır, ilk kez nü kadın modeli kız atölyesine sokar, cesur kimliğiyle aralarında Müzdan Arel (1897-1986), Güzin Duran (1898-1981), Nazlı Ecevit (19001985), Belkıs Mustafa (1896-1925), Fahrelnisa Zeid (1901-1991), Aliye Berger'in (1903-1974) de olduğu öğrencilerinin açık havada resim yapmasına, canlı modelden çalışmasına ve eserlerinin görünürlük kazanmasına destek verir. İsmi İnas Sanayi-i Nefise Mektebi ile özdeşleşmiş olan Mihri Hanım, Müfide Kadri’nin ölümünden sonra 1913-1914 yıllarında Dar-ül Muallimât-1 Âliyye' de görev yapar. ${ }^{19}$ Çağdaş Türk Sanatı tarihinde özel bir yere sahip olan ve bu yeni Osmanlı kadını kimliğini temsil eden ilk kadın ressamlar Mihri Hanım ve Müfide Kadri’dir.

İnas Rüştiyesi’ne kızların gönderilmesi için aileleri teşvik etmek gerekir. Teşvikte kullanılan gerekçeler ilginçtir ve Batı'da daha önceye tarihlenen gerekçelerle benzerlik taşır: Eğitim gören kızlar daha itaatkar, iffetli ve kanaatkar olacak ve böylece ailelerine refah ve saadet getirecekler, ${ }^{20}$ iyi anne ve iyi eş olacaklardır. Mektebe ilk başvuran öğrenci, Müzdan Sait Hanım’dır. İkinci öğrenci Muide Esat Hanım, üçüncüsü Belkıs Mustafa Hanım ve dördüncüsü ise Nazire Osman'dır. ${ }^{21}$ Güzin Duran ve Nazlı Ecevit, İnas Sanayi-i Nefise Mektebi’nin verdiği ilk mezunlar arasındadır. ${ }^{22}$ Öğrencilerin büyük bir kısmının misafir, kayıtlı öğrencilerin yarısından fazlasının terk eğilimli olduğu ve diploma sınavı her dönem gerçekleşmediği için öğretmenlik için yeterlilik belgesi verilen öğrencilerin mezun olmayı beklemeden okuldan ayrıldıklarını hesaba katarak 1917-1922 yılları arasında okulun verdiği toplam diploma sayısının 50 civarında olduğu düşünülebilir. ${ }^{23}$

Harika Hanım, İnas Sanayi-i Nefise Mektebi'nde öğrenci olmasa da dönemin ünlü kadın sanatçıları gibi mektepte konuk öğrenci olarak Nazmi Ziya'dan dersler alır. ${ }^{24}$

Marmara Üniversitesi, 1996), 46, 47. İlk eşinden 1920'li yılların başında boşandıktan sonra, babasının ismi olan Rasim'i kullanır. Yaşadığı dönemde ismini Mihri Rasim veya Mihri Hanım olarak kullanır. 7 Mart-9 Haziran 2019 tarihleri arasında Salt Galata'da açılan Mihri: Modern Zamanların Göçebe Ressamı sergisi Mihri Hanım hakkında yapılan en kapsamlı çalışma ve sergidir ve bu serginin bir özelliği soyadı meselesinin altını çiziyor olmasıdır. Sergide ilk eşinin soyadından (Müşfik) ve babasının isminden (Rasim) bağımsız olarak ele alınmış, sadece Mihri ismi tercih edilmiştir. Bütün bunların ışı̆̆ında makalede Mihri Hanım olarak kullanılması tercih edilmiştir.

19 Pelvanoğlu, "Kadın, Eğitim, Sanat," 58, 46.

20 Pelvanoğlu, "Kadın, Eğitim, Sanat," 44.

21 Okulun 3 numaralı öğrencisi Belkıs Mustafa'nın not defterleri İnas Sanayi-i Nefise Mektebi’nin ilk öğrencileri ve okulda sunulan dersler hakkında yapılan araştırmalara ışık tutan en önemli kaynaklardan biri olarak görülse de burada bulunan bilgilerin ne derece güvenilir ya da eksiksiz olduğu tartı̧̧ma konusudur. 1914 tarihli defterlerden ilk yıl kayıt olan öğrenci sayısının 33 olduğu anlaşılmaktadır. Burcu Pelvanoğlu, 2007 tarihli çalışmasında bu sayıyı 35 olarak verir. Bkz. Uğurgül Tunç, "Osmanlı Modernleşmesinde Eğitim, Sanat ve Kadın: İnas Sanayi-i Nefise Mekteb-i Âlisi Örneği” (Yüksek Lisans Tezi, İstanbul Teknik Üniversitesi, 2018), 81 .

22 Taha Toros, Ilk Kadın Ressamlarımız, 42-45.

23 Tunç, “Osmanlı Modernleşmesinde Eğitim, Sanat ve Kadın: İnas Sanayi-i Nefise Mekteb-i Âlisi Örneği”, 80.

24 Nazmi Ziya'dan ders alan ünlü isimlere Melek Celal Sofu (1896-1976), Vildan Gezer (1889-1974), Emine Fuad Tugay (1897-1973), Sabiha Rüştü Bozcalı (1904-1998) örnek verilebilir. Bkz. Fatma Ürekli, "Güzel Sanatlar Eğitiminde Osmanlı Hanımlarına Açılan Bir Pencere, İnas Sanayi-i Nefise Mektebi," Tarih ve Toplum Dergisi 231 (2003), 58. 
1911 'de okuldan mezun olmasına rağmen yaşı küçük olduğu için öğretmen olamaz. Bu dönemde Fransız okuluna gider. Teyzesiyle serbest resim gezilerine çıkar. ${ }^{25}$

\section{Harika Lifij'in Resimleri Üzerine}

Harika Hanım resimlerine tarih vermemiştir. Anılarında anlattığg mekânlar ve kullandığ1 renkler göz önünde bulundurularak makalede bir kronoloji oluşturulmaya çal1şılmıştır. Ayla Ödekan’a göre Mihri Hanım ve Hale Asaf dışındaki kadın sanatçılar ve özellikle erkek sanatçı eşleri ikinci planda kalmayı yeğlemişlerdir. Sanatları da portre ve manzara konularıyla sınırlıdır. ${ }^{26}$ Burada bahsedilen erkek sanatçı eşleri Güzin Du$\operatorname{ran}^{27}$ ve Harika Hanım'dır. Harika Hanım da manzara resimleri yapmasına rağmen mitolojik ve alegorik resimleri diğerlerinden farklı yönü olarak dikkat çeker. Üslubunun gelişiminde aldığı eğitimlerin etkisi büyüktür. Müfide Kadri’den figürün ve desenin önemini, romantik yaklaşımı; Avni (Lifij)'den empresyonist tekniğini öğrenir. Resmin konusuna göre tekniği de değişir. Doğadan manzaralar yapması da tüm sanat hayatında açık havada resim yapma tekniğini sevdiğini gösterir. Sanatçının manzaralarında İstanbul'un çeşitli yerlerini özellikle Yeşilköy’ü, Fatih Camii ve çevresini resmettiği görülür. Harika Hanım, Dar-ül Muallimât-1 Âliyye'den mezun olduğu 1911 yılı ve sonrasında doğa çalışmaları yapar ve konu olarak sık gittikleri mekânları tercih eder. Annesinin bir ahbabının Yeşilköy'de oturduğundan ve 31 Mart vakası (13 Nisan 1909) çıktığında Yeşilköy'e gidemediklerinden bahseder. ${ }^{28}$ Yeşilköy'den Manzara adlı çalışması bu dönem çalışmaları içerisinde olabilir (G. 1). ${ }^{29}$ Zamanının Yeşilköy’ünü deniz ve ağaç manzarası ile betimler. Yeşilköy'ün 1926 yılından önceki adı Ayastefanos'tur. Bu resmin önce 1917 yılında Savaş Resimleri ve Diğerleri Sergisi'nde ve 1918 yılında Viyana Sergisi'nde sergilenen Ayastefanos (Poşad) resmi olduğu tahmin edilmektedir.

25 Harika Sirel Lifij' in Yaşamı, Prof. Şazi Sirel-Ayten Sirel Arşivi, 9.

26 Ayla Ödekan, "İmgenin Dönüşümü," Hayal ve Hakikat: Türkiye’den Modern ve Çağdaş Kadın Sanatçılar/ Dream and Reality: Modern and Contemporary Women Artists from Turkey, ed. Esin Eşkinat, (İstanbul: İstanbul Modern Sanat Müzesi Yayınları, 2011), 62. Ayla Ödekan bu makalesinde kadın sanatçıların çalışmalarını inceleyerek detaylı bir karşılaştırma yapar.

27 Güzin Duran ile ilgili ayrıntılı bilgi için bkz. İlkay Canan Okkalı, "Güzin Duran: Eşinin Gölgesinde Bir Kadın Ressam,” Sanatın Gölgedeki Kadınları, der. Özlem Belkıs ve Duygu Kankaytsın (İstanbul, Ayrıntı Yayınları, 2018), 444-456.

28 Harika Sirel Lifij 'in Yaşamı, Prof. Şazi Sirel-Ayten Sirel Arşivi, 6.

29 Bu resmin tarihi Gören, “Türkiye'de Güzel Sanatlar Okulları: 2, İnas Sanayi-i Nefise Mektebi, Kadın Ressamlar, Özel Resim Atölyesi ve Resim Kursları,” 24'de 1917 olarak, 2019 yılında Sabancı Müzesinde aç1lan Avni Lifij sergisinde ve Sirel Lifij, "Eşim Avni Lifij ve Ben...," Sanat Çevresi 45 (Temmuz 1982), 16'da ise 1912 olarak belirtilmiştir. Anılarında 1909 yılında Yeşilköy'deki annesinin ahbabından bahseder. Yeşilköy’ün 1926 yılından önceki adının Ayastefanos olduğu düşünülürse bu resmin 1917-1918 yılı Galatasaray Sergisi'nde sergilenen Ayastefanos (Poşad) resmi olduğu tahmin edilir. Daha erken tarihte resmi yaparak daha sonra da sergilemiş olabilir. Bu yüzden makalede resmin tarihi 1912 olarak bırakılmıştır. 


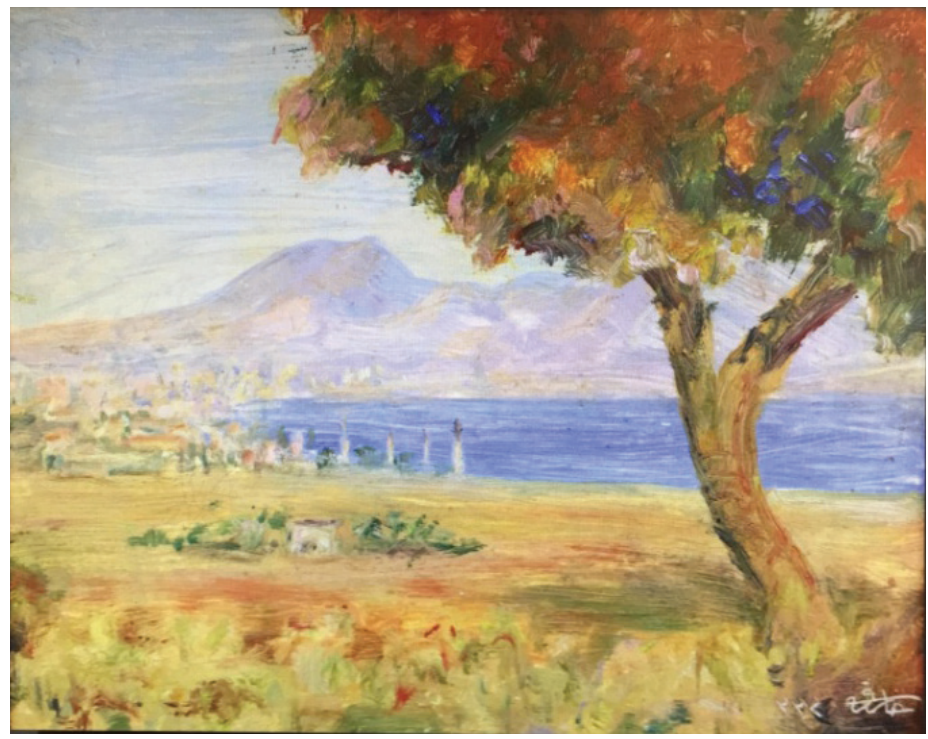

G. 1. Harika Şazi Sirel Lifij, Yeşilköy'den Manzara/Ayastefanos, 1912, Tuval üzerine yağlıboya, 20x25 cm, Nilüfer Sirel koleksiyonu. (Gören, “Türkiye’de Güzel Sanatlar Okulları: 2, İnas Sanayi-i Nefise Mektebi, Kadın Ressamlar, Özel Resim Atölyesi ve Resim Kursları,” 24)

Harika Hanım, 1914 yılında 18 yaşındayken Osmanlı İmparatorluğu'nun ilk deneme okulları olan İstanbul'da Numune Mektebi'ne ${ }^{30}$ resim öğretmeni olarak atanır. Birçok kız okulunda ve lisede resim öğretmenliği yapar. Öğretmenlik yaparken güncel resim sergilerini de takip eder. II. Meşrutiyet'in etkisiyle Doğu'nun ruhu ile Batı eğitiminin birleşmesinden doğan düşünen, okuyan kadın profilinin bir örneği; dönemin romanlarında bahsedilen ideal kadın tipinin, Süs ve Mehasin gibi kadınlara yönelik dergilerde yayımlanan çocuk yetiştirme, iyi bir eş olma, ahlak, eğitim, kadınların terakkisi, meslek hakkı vb. konular ${ }^{31}$ takip eden siyasi ve sosyal gündemi izleyen entelektüel kadın tipinin görünen yüzü olur. Henüz 18 yaşında yolun başında bir genç ressam ve öğretmenken yapmış olduğu portresinde kadın sanatçı olarak yetiştiği dönemde var olma ve özgürleşme çabasının yansıması hissedilir. 1914 tarihli Otoportre (G. 2) çalışmasında gerçekçi bir anlayışla kendini ciddi bir şekilde betimler. Bu portre, elinde firçası ile duruşu, yüz ifadesi ile güçlü bir sosyal-psikolojik ifade taşıması yanında yaşadığı zamana tanıklık etmesi açısından önemlidir. Bu resim 20. yüzyılın başında bir kadın sanatçı olarak Batılı kimliğinin de göstergesidir. Kompo-

30 Osmanlı İmparatorluğu'nda ilk modern deneme ilkokulları, diğer adıyla Numune Mektepleri (örnek okullar) ya da Usul-ü Cedid Íptidaileri 1872 İstanbul'da açılmıştır.1876 yılında kabul edilen Kânûn-1 Esâsî, kız ve erkek çocuklar için ilköğretimi anayasal bir zorunluluk hâline getirmiştir. Başkent İstanbul dışında Anadolu'da bulunan Numune Mektepleri'nin (örnek okullar) sayısı 1885 yılında 44 olmuştur. Taşrada bulunan bu okulların öğretmen ihtiyacını karşılamak için 1880'li yıllarda 14 kentte, ilk öğretmen okulları kurulmuştur. "Numune Mektepleri (Örnek okullar),” erişim 14 Nisan 2020, http://www.istanbulkadinmuzesi.org/ numune-mektepleri

31 II. Meşrutiyet dönemi kadının toplumsal konumu ve eğitimi için bkz. Ümüt Akagündüz, II.Meşrutiyet Döneminde Kadın Olmak (İstanbul: Yeni İnsan Yayınevi, 2015). 
zisyon, açık-koyu, gölge-1şık gibi resmin temel teknik prensiplerini uygulama kaygısı otoportrede dikkati çeken unsurdur.

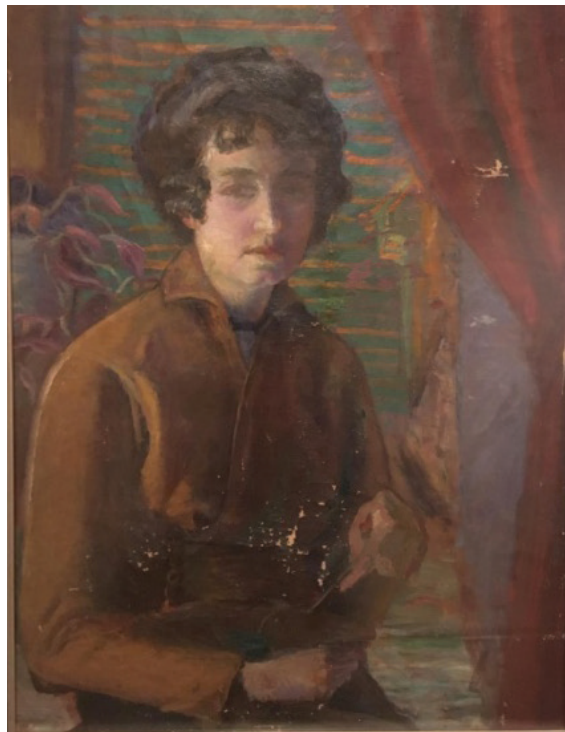

G. 2. Harika Şazi Sirel Lifij, Otoportre, 1914, Tuval üzerine yağlıboya, 71x54 cm. Belkıs\&Erdal Aksoy koleksiyonu. (Gören, “Türkiye’de Güzel Sanatlar Okulları: 2, İnas Sanayi-i Nefise Mektebi, Kadın Ressamlar, Özel Resim Atölyesi ve Resim Kursları,” 15)

Osmanlı'nın son dönemlerinde sarayın Batılılaşma idealleri doğrultusunda modern resmin gelişiminde Saray sanatçılarının yükselişi ${ }^{32}$ ve sanatçıların otoportre resimleri önemli yer tutar. Ahmet Kamil Gören "Batı sanatında olduğu gibi, Türk Resim Sanatı'nda da otoportrenin özgür bir ifadenin sonucu olarak yaygınlık kazanmaya başlamasının aynı zamanda, bireyin de özgürleşmesine işaret ettiğini"”33 belirtir. Burcu Pelvanoğlu'nun Hale Asaf için kullandığ özellikle portre ve otoportrelerde kendini gösteren, hem iç dünyaların yansıtılması hem de bunun "kadın olmakla birleştirilebilmesi; görünürde olanın, kendisine dayatılanın arkasına geçme çabası, kadın sanatçıların kendilerini ortaya koyma arzusunu gösterir" ${ }^{\prime 34}$ ifadesini Fatmagül Berktay, Hayal ve Hakikat sergisi içinde yer alan tüm kadın sanatçılar için kullanır. Bu açıdan bakıldığında Harika Hanım'ın otoportresi de kendini görünür kılma meselesinin bir sonucudur.

32 Ahmet Kamil Gören, "Türk Resminin Önemli Bir Odağı: Saray Koleksiyonu,” İhtişam ve Tevazu Padișahın Ressam Kullarl, (İstanbul: TBMM Milli Saraylar Yayını, 2012), 15.

33 Ahmet Kamil Gören, Türk Resim Sanatı'nda otoportrenin gelişim serüvenini izleyebilmek için, birbirine karşıtlık oluşturan Avni Lifij'in Pipolu- Kadehli Otoportresi ile Şeker Ahmed Paşa'nın Otoportresi'ni karşılaştırır. İki resim arasındaki fark, düş peşinde koşan bir sanatçıyla, sanatına fotoğraf işlevi yükleyen bir sanatçının doğayı resmetme anlayışııın nasıl çatıştı̆̆ına iyi bir örnek oluşturur. Otoportre için bkz. Ahmet Kamil Gören, "Özgür Bir İfadenin Sonucu Olarak Ressamın Kendi Sureti: Otoportre," Nurhan Atasoy'a Armağan, ed. M. Baha Tanman (İstanbul: Lale Yayıncılık Kültür ve Sanat Yayınlar1-1, [Haziran] 2014), 179.

34 Pelvanoğlu, "Kadın, Eğitim, Sanat," 149'dan aktaran Fatmagül Berktay, "Hayal ve Hakikat ya da Hayalin Hakikatine Bitmeyen Yolculuk", Hayal ve Hakikat: Türkiye'den Modern ve Cağgaș Kadın Sanatçllar/Dream and Reality Modern and Contemporary Women Artists from Turkey, ed. Esin Eşkinat (İstanbul: Modern Sanat Müzesi, 2011), 39. 
Avni Lifij'in eserlerini ve gazetedeki yazılarını takip ederek beğenen Harika, 1915 yılında gazetede gördüğü bir ilan üzerine, Beyoğlu Tünel'de açılan Avni Lifij Resim Sergisini ziyaret eder ve Lifij'in küçük bir resmini o günkü para ile 30 liraya satın alır. ${ }^{35}$ Avni Lifij'le tanışmaları ise 1917 yılında Viyana Sergisi’nin jürisinde olur. Yedi kişilik jüride Ruhi (Arel), Hikmet (Onat), Feyhaman (Duran), İbrahim (Çallı) ve Avni (Lifij) bulunur. ${ }^{36}$ Jüri üyeleri Harika'nın resimlerini değerlendirmek için evine gelirler. Viyana sergisi Avrupa'da Türk ressamları tarafından açılacak ilk sergi olması bakımından önemli bir sergidir. Ruşen Zamir Hanım'la sergiye seçilen iki kadından biri olarak Harika Hanım'1n sekiz resminin Viyana'da sergilenmesi sanatı ve kariyeri açısından önemlidir. Savaşı sevmeyen Harika Hanım mitolojik konulu Ilahlar Ĕgleniyor (G. 3) isimli bir resim yapar. Kendi eserini şöyle anlatır: "İki gladyatör resmi yaptım. Venüs'e (Afrodit) bir kol takarak eline bir çelenk verdim ve savaş kavramı ile bir anlamda alay ettim. Yine o sırada Ahenk (G. 4) adlı bir başka resmi tamamladım." 37 Ilahlar Eğleniyor adlı mitolojik konulu çalışmada ağaca yaslanmış flüt çalan Marsias, karşısında Afrodit, Apollon, Athena gibi mitolojik figürlerin yer aldığı görülür. Arkada antik dünyanın tapınaklarından birinin olduğu alegorik bir resimdir. Ilahlar Eğleniyor resmi Tomur Atagök’e göre Neo-klasik tarzda yapılmış bir eserdir. ${ }^{38}$

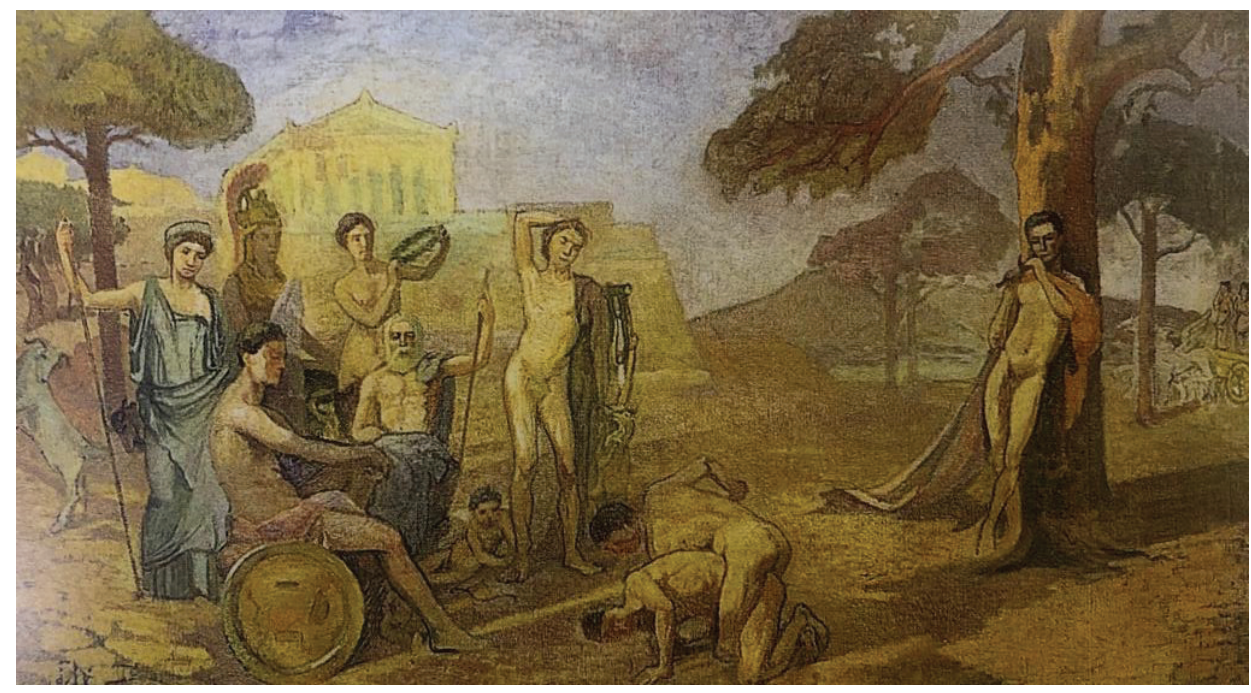

G. 3. Harika Şazi Sirel Lifij, İlahlar Eğleniyor, 1917, Tuval üzerine yağlıboya, 90x147 cm, Nilüfer Sirel koleksiyonu (Gören, Türk Resim Sanatında Şişli Atölyesi ve Viyana Sergisi, 100.)

35 Sirel Lifij, "Eşim Avni Lifij... ve Ben...," 17.

36 Gören, Türk Resim Sanatında Şişli Atölyesi ve Viyana Sergisi, 48-49.

37 Sirel Lifij, “Eşim Avni Lifij... ve Ben...”, 17. İlahlar Eğleniyor resmi 1917-1918 Viyana'da sergilenen katalogda İlahlar Nezdinde/Tanrlarla olarak geçen resimdir. Resmin ismini Harika Hanım makalesinde İlahlar Eğleniyor olarak kullandığ için makalemizde bu isim tercih edilmiştir.

38 Tomur Atagök, “Kadın ve Sanat,” Cumhuriyet’ten Günümüze Kadın Sanatçılar, Çağlarboyu Anadolu’da Kadın Sergileri (İstanbul: TC. Kültür Bakanlığı Anıtlar ve Müzeler Genel Müdürlüğü, 1993), 19. 
Harika Hanım'ın Türk resminde erken örneklerini 1914 Kuşağı'nda gördüğümüz mitolojik, alegorik resimleri genç yaşında yapmaya cesaret etmesi önemlidir. Türk resminde alegorik öğelere Avni Lifij' in Atölye resmi ${ }^{39}$ ve Nazmi Ziya'nın Paskalya Sabahı resmi örnek verilebilir. Harika Hanım'ın erken çalışmalarından simgesel öğeler taşıyan Ahenk/Armoni (G. 4) resminde gizemli bir doğa görünümü betimlenir. Solda yer alan bir ağacın altında çıplak bir genç kız oturur ve gökyüzünde uçan muhtemel bir melek figürüne doğru bakar. Sağ tarafta arkada küçük bir yap1 ile kompozisyonun ortasındaki küçük bir akarsuyun döküldüğü küçük şelale bulunur. ${ }^{40}$ Konu olarak sembolik/romantik etkiler taşıyan resim teknik olarak klasik ve empresyonist tarzı birleştirir. Harmonia (Armoni/Ahenk) Afrodit'in savaş tanrısı Ares'le birleşmesinden doğan üç çocuğundan biridir. Diğerleri Phobos (Korku) ve Deimos'dur (Dehşet). Bu üç özellik Afrodit' in kişiliğindeki olumlu-olumsuz yönleri ve çelişkileri simgeler. İlk bakışta Harmonia (Ahenk) isminin Ares'in Afrodit'den doğan çocuğuna verilmiş olması tuhaf gözükse de; onun sonraları savaşa giren bir toplum içerisinde ortaya çıkan büyük dayanışmayı ve sevgiyi sembolize ettiği görülür. ${ }^{41}$ Bu bilgi mitolojiyi bilen ve ilgilenen Harika Hanım'ın Savaş Resimleri konulu bir sergide neden bu konuyu ele aldığını açıklamaktadır. Ağaçlarda ve manzarada yeşilin tonlarını kullanan sanatçı, örtünün kırmızılığı ile kompozisyonun ana figürü olan çıplak kıza dikkati çeker. Harika Hanım, renk konusunda kararsız kaldığında deseni başka bir kağıda çizip birkaç rengi desen üzerinde deneyerek çalışır. ${ }^{42} \mathrm{Bu}$ yöntemle çalışmasına örnek olarak Ahenk/Armoni resminde ağaca dayanmış genç

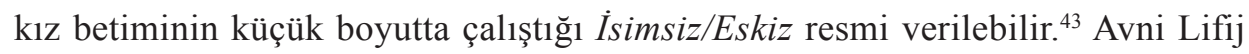
de aynı yöntemi kullanır. Harika Hanım'ın Avni Lifij'le evlenmeden önce de romantik $^{44}$, alegorik ve mitolojik resimler yaptığg düşünülürse etkileşimin çift yönlü olduğu sonucuna ulaşılabilir.

39 Gören, "Kısa Yaşamının Büyük Mirasıyla Avni Lifij," 38-39. Resim bilgileri: Avni Lifij, Atölye, 56x40 cm, tuval üzerine yağlıboya, Ankara Resim ve Heykel Müzesi Koleksiyonu; Nazmi Ziya, Paskalya Sabahı, 1935, Tuval Üzerine yağlıboya, 60x 73 Sabancı Üniversitesi Sakıp Sabancı Müzesi

40 Gören, Türk Resim Sanatında Şişli Atölyesi ve Viyana Sergisi, 99-100.

41 Robert Graves, Yunan Mitleri, Tanrılar, Kahramanlar, Söylenceler, çev. Uğur Akpur (İstanbul: Say Yayınları, 2012), 81, 87.

42 Harika Sirel Lifij' in Yaşamı, 10, 12.

43 Harika Sirel Lifij, İsimsiz/Eskiz, Karton üzerine yağlıboya, Belkıs-Erdal Aksoy koleksiyonu. Bu çalışma Avni Lifij Çağının Yenisi sergisinde yer almıştır.

44 Gören, Türk Resim Sanatında Şişli Atölyesi ve Viyana Sergisi, 155. 


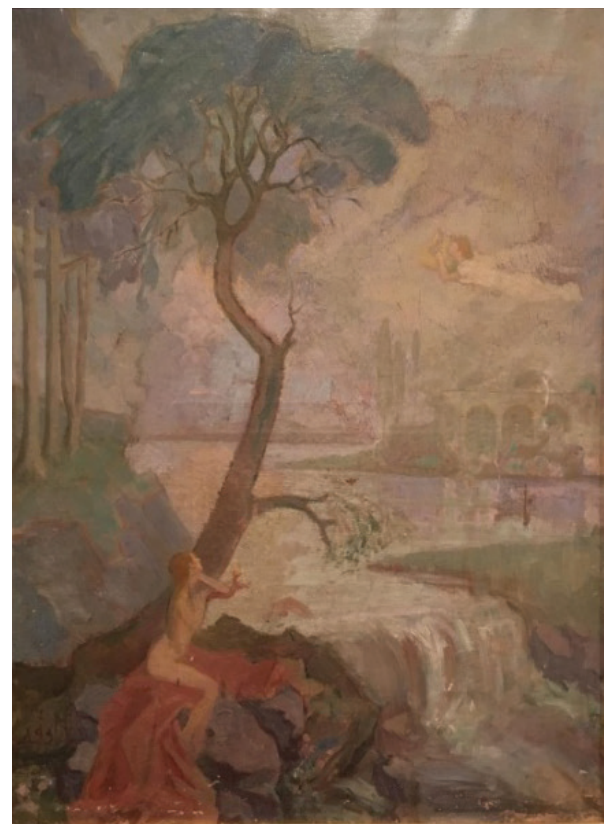

G. 4. Harika Şazi Sirel Lifij, Ahenk/Armoni, 1917, Tuval üzerine yağlıboya, 75x55 cm. Banu Aksoy Tarakçığlu koleksiyonu (Avni Lifij Sanat Yazıları, haz. Ömer Faruk Şerifoğlu, 99)

Literatürde Sarı Bina Önündeki Sokak olarak geçen resmin Viyana Sergisi için yaptığı Selvi Ağacı resmi olduğu Şişli Atölyesi ve Viyana Sergisi kitabında yer alan sergi fotoğrafından anlaşılır. ${ }^{45}$ Sarı Bina Önündeki Sokak/Selvi Ă̆acı (G. 5) adlı çalışmasında sarı, yeşil, kahverengi tonları kullanarak boş bir sokağı ve selvi ağacını betimler. $\mathrm{Bu}$ resimlerinde paletindeki renkler akşam güneşinin altında boyadığı görünümler ve İstanbul'un şiirsel havaya bürünmüş köşeleridir. ${ }^{46}$ Akşam güneşinin arkadaki binaya vurduğu resimde koyudan açık tonlara geçiş vardır.

45 Gören, Türk Resim Sanatında Şişli Atölyesi ve Viyana Sergisi, 68-69.

46 Bu tanımı Nurullah Berk, Avni Lifij' in manzara resimleri ve poşadları için yapmıştır. Her iki sanatçının da birbirinden etkilenebileceği düşünülerek ve benzerlikler göz önünde bulundurularak makalede Harika Hanım için de kullanılmıştır. Avni Lifij' in Zeyrek ten Fatih Camii, Vefa'da Akşam, Vefa'dan Fatih Cami gibi yapıtları bu benzerliklere örnek verilebilir. Resim bilgisi: Avni Lifij, Zeyrek'ten Fatih Camii, karton üzerine yağlıboya, 9x13,9 cm, Ayten \& İ. Şazi Sirel Koleksiyonu; Avni Lifij, Vefa'da Akşam, karton üzerine yağlıboya, 8,7 x14 cm, Ayten \& İ. Şazi Sirel Koleksiyonu; Avni Lifij, Vefa'dan Fatih Camii, karton üzerine yağlıboya, 10,9 x 24,1 cm, Ayten \& İ. Şazi Sirel Koleksiyonu. Daha ayrıntılı bilgi için bkz. Gören, "Kısa Yaşamının Büyük Mirasıyla Avni Lifij," 38-39. 


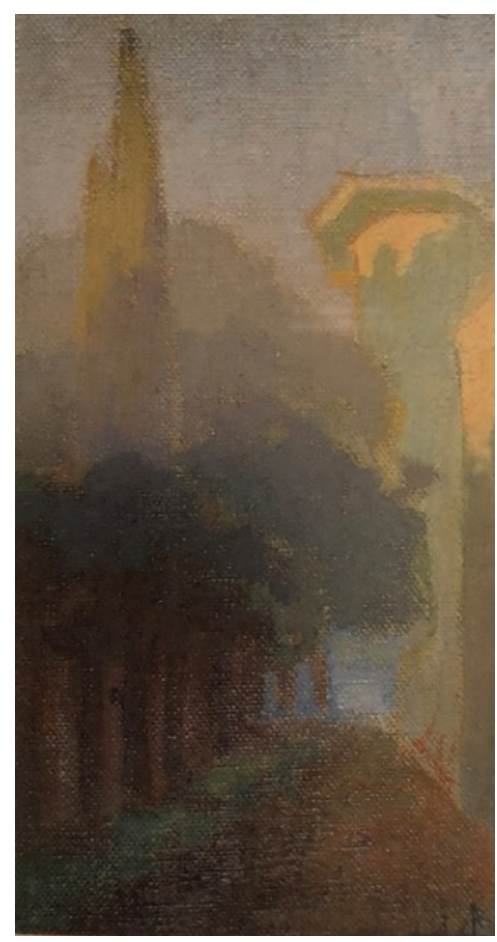

G. 5. Harika Şazi Sirel Lifij, Sarı Bina Önündeki Sokak/Selvi Ă̆acı, 1917, Tuval üzerine yağlıboya, 37x 27,5 cm, Belkıs Aksoy koleksiyonu. (Gören, “Türkiye'de Güzel Sanatlar Okulları: 2, İnas Sanayi-i Nefise Mektebi, Kadın Ressamlar, Özel Resim Atölyesi ve Resim Kurslar1,” 23.)

Harika Hanım'ın Camili Peyzaj (G. 6) çalışması Avni Lifij'le evliliğinden sonraki gezilerin bir yansıması olabileceği gibi, Avni Lifij’ in Galatasaray Sergileri yazılarında övdüğü poşadlarından da olabilir. Resimde önde ağaçlar, arkada kubbeli bir cami betimlemiştir. Sarı, yeşil, kahverengi tonları kullanarak hızlı firça vuruşları ile çalıştığı anlaşılır. 


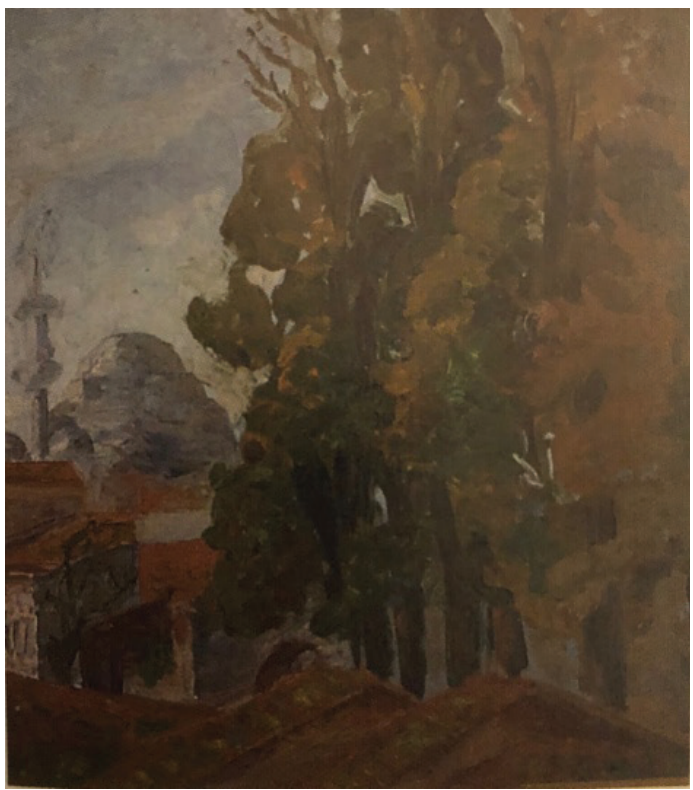

G. 6. Harika Şazi Sirel Lifij, Camili Peyzaj, Tuval üzerine yağlıboya, 27,5x 29,2 cm, Belkıs Aksoy koleksiyonu. (Gören, “Türkiye'de Güzel Sanatlar Okulları: 2, İnas Sanayi-i Nefise Mektebi, Kadın Ressamlar, Özel Resim Atölyesi ve Resim Kursları,” 17)

Harika Hanım, 1920’de mezun olduğu İstanbul Dar-ül Muallimât-1 Âliyye'de resim öğretmenliğine başlar. ${ }^{47} 11$ Temmuz 1919 yılında Avni Lifij'le nikâhlanır, o sıralar salgın olan İspanyol gribi nedeniyle 25 Mart 1922 yılında tören yaparak evlenirler. ${ }^{48}$ Anılarında 1918'de İstanbul kuşatma altındayken Avni Lifij'le Fatih Camii avlusunda karşılaşarak Sultan Selim Camii'ne resim yapmaya gittiklerini anlatır. ${ }^{49}$ Evlendikten sonra da Avni Lifij'le birlikte çalışmalar yapmaya devam ederler. 1922 yılında evlendikten sonra Laleli'de Tayyare Evleri'nde yaşamaya başlarlar ve bu daireden geri plandaki Fatih Camii de gözükür. ${ }^{50}$ Buna bağlı olarak Fatih Camii/Ramazan Gecesi resmini 1922'de evlendikten sonra yapmış olabileceği ve bu resmin 1923 yılında Ankara Sergisi'nde sergilenen Ramazan Gecesi isimli eser olduğu düşünülmektedir. ${ }^{51}$

Fatih Camii /Ramazan Gecesi ${ }^{52}$ (G. 7) resmi Ramazan gecelerine has iki minare arasında Ya Fettah yazan ışıklı mahya ile camiye yönelen insanları betimlemektedir.

47 Cumhuriyeti Karşılayan Kadın Ressamlar Kataloğu (İstanbul: KÜSAV, 1998).

48 Sirel Lifij, "Eşim Avni Lifij... ve Ben...," 17.

49 Harika Sirel Lifij’'in Yaşamı, 12.

50 Ahmet Kamil Gören, Avni Lifij (İstanbul: YKY, 2001), 269.

51 “Resim Sergisi," Hakimiyet-i Milliye, 15 Teşrin-i Evvel 1923; Halil Özyiğit, "1920-1928 Yılları Arasında Süreli Yayınlarda Kültür ve Sanat Yorumları: Resim” (Yüksek Lisans Tezi, Pamukkale Üniversitesi, 2005), 290.

52 Harika Sirel Lifij’in Müzayede kataloğunda Cami olarak tanımlanan ve imzası okunamadığı belirtilen çalışma Ömer Faruk Şerifoğlu tarafından sanatçının imzası okunarak literatüre kazandırılmıştır. Ömer Faruk Şerifoğlu ile yapılan 17.04.2020 tarihli görüşme. 
Harika Hanım gündelik yaşam içerisinden bir sahneyi konu alır. Resimde mavi-siyah renkleri gecenin karanlığını vurgulamak için kullanır. Türk resminde erken dönemde gece resimleri pek sık görülmez. Buna karşıllk gece, 1914 Kuşağı içinde Feyhaman Duran, Avni Lifij gibi sanatçıların resimlerine konu olmuştur. ${ }^{53}$

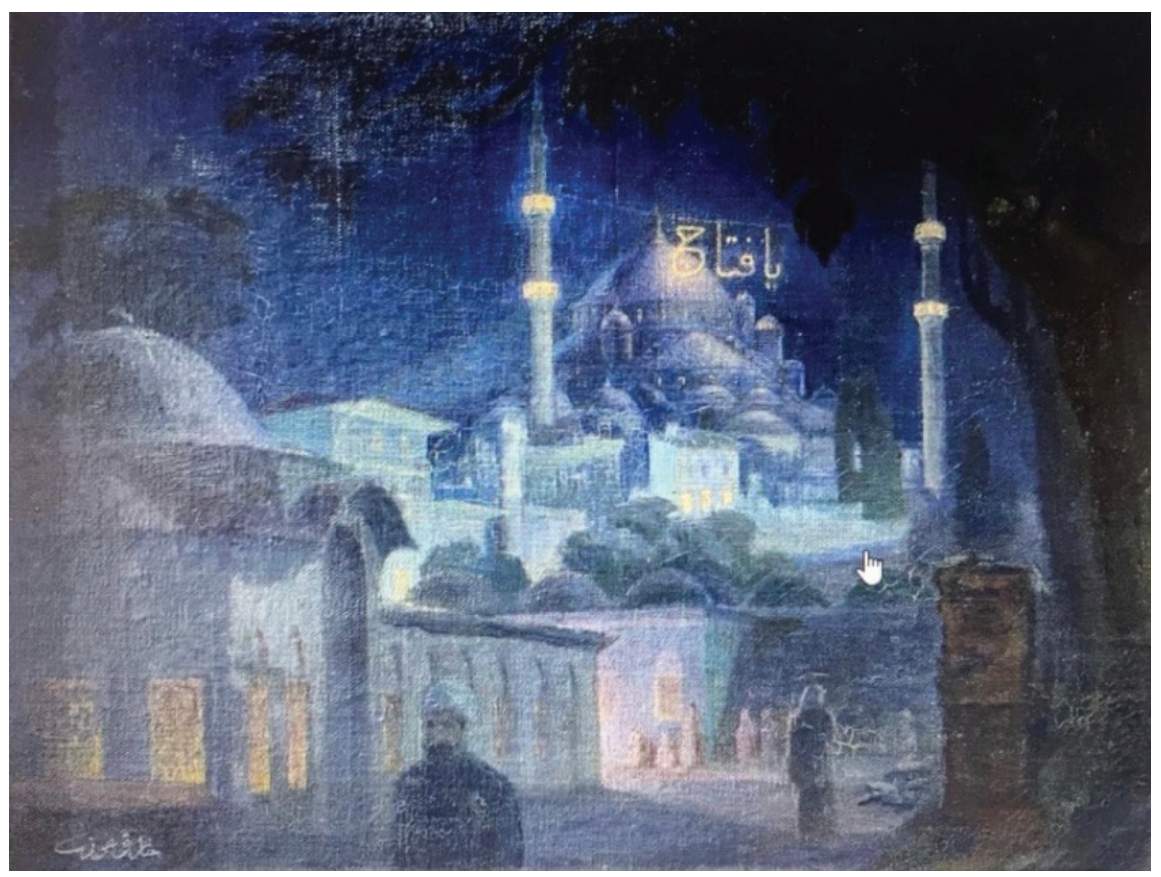

G. 7. Harika Şazi Sirel Lifij, Fatih Camii/Ramazan Gecesi, eski Türkçe imzal1, 1923, Pres tuval üzerine yağlıboya, 45x 55 cm, Alpaslan Aktuğ koleksiyonu (Ares Osmanlı, Çağdaş, Karma Sanat Eserleri Müzayedesi, 15.Online Müzayede, https://www.yumpu.com/tr/document/read/63174600/ares-50)

Harika Hanım, Muazzez Bey'in ${ }^{54}$ özel atölyesine devam eder. Burada hocalık yapan Nazmi Ziya, Mehmed Ruhi ve Feyhaman Duran'dan da sanat eğitimi alarak kendini geliştirir. ${ }^{55}$ Hocalarının eğilimlerinin Empresyonizm etkili olması Harika Hanım'1 da etkiler.

Ağaçlı Sokak ve Sarı Bina (G. 8) resminde fevkani sarı bir bina ve bahçesinde altı figür betimler. Figürlerin çoğu kadındır. Özellikle II. Meşrutiyet'in ilanından sonra kadını başı başına bir konu olarak ele alan ressamlar daha çok gezi kültürünün bir

53 Resim bilgisi: Avni Lifij, Gece, Mukavva üzerine yağlıboya, 17x13,5 cm, Sakıp Sabancı Müzesi koleksiyonu env. No. 200-0198, Avni Lifij Çağının Yenisi (İstanbul: Sabancı Üniversitesi Sakıp Sabancı Müzesi Yayını, 2019), 177. Feyhaman Duran, Manzara, karton/tuval üzerine yağlıboya, 27x19 cm, İstanbul Üniversitesi Resim Koleksiyonu env. No. 786/2000.

541916 Birinci Galatasaray Sergisine Ilkbahar, 1926’daki Galatasaray Sergisi’ne Ortaoyunu, 4. Ankara Sergisi’ne Lale Devri resmi ile katılır. Özyiğit, “1920-1928 Yılları Arasında Süreli Yayınlarda Kültür ve Sanat Yorumları: Resim”, 118, 207. Eşref Üren'e hocalık yapan Muazzez Bey ve atölyesi hakkında daha fazla bilgi edinilememiştir.

55 Gören, Türk Resim Sanatında Şişli Atölyesi ve Viyana Sergisi, 154. 
parçası olan mesire yerlerinde kadınları tek başlarına, ikili olarak ve nadiren de olsa karşı cinsle temas hâlinde gösterirler. ${ }^{56}$ Harika Lifij' in resminde de figürlerin giyimkuşamı özellikle kadınların şapkaları çalışmanın Cumhuriyet dönemine ait olabileceğini düşündürür. Gökyüzünün renkleri, gökkuşağının renkleri ile daha yumuşak ve şiirsel bir ifade kazanır. Avni Lifij'in $M a n z a r a^{57}$ resmindeki renkler ve gökkuşağı ile benzerlik taşır.

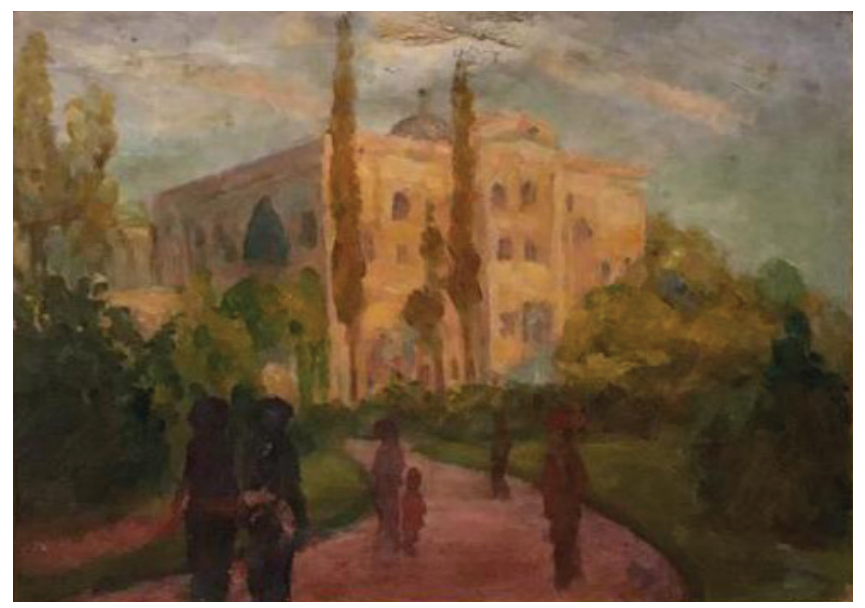

G. 8. Harika Şazi Sirel Lifij, A $\breve{g} a c ̧ l ı ~ S o k a k$ ve Sarı Bina, kartona yapıştırılmış tuval üzerine yağlıboya, 15,5x 29 cm, Belkıs-Erdal Aksoy koleksiyonu. (Gören, “Türkiye'de Güzel Sanatlar Okullar1: 2, İnas Sanayi-i Nefise Mektebi, Kadın Ressamlar, Özel Resim Atölyesi ve Resim Kurslar1", 24.)

Harika Lifij' in resimlerinin döneminin sanat ortamındaki yerini anlayabilmek açısından sergilere katıldığı yıllardaki çağdaşları ve hocaları olan ressamların çalışmaları karşılaştırılabilir. Yine de bu karşılaştırma yapılırken her sanatçının farklı olduğu unutulmamalidir. ${ }^{58}$

\section{Katıldığı Sergiler ve Hakkındaki Eleştiri Yazıları}

Harika Hanım'ın katıldığı bilinen ilk sergi, Birinci Galatasaraylılar Sergisi'dir. Galatasaray Sergileri 1916 yılından başlayarak 1951 yılına kadar devam eden, açılış günlerinde devletin üst düzey yöneticilerinin hazır bulunduğu, ressamları ödüllendirdiği ve yapıt satın alarak desteğini belirgin bir biçimde gösterdiği sergilerdir. Aynı zamanda bu sergiler Osmanlı toplumunu çağdaş sanat ve sanatçılar ile buluşturmak

56 Ahu Antmen, Kimlikli Bedenler Sanat, Kimlik, Cinsiyet (İstanbul: Sel Yayınc1lık, 2013), 40.

57 Avni Lifij Çă̆ının Yenisi (İstanbul: Sabancı Üniversitesi Sakıp Sabancı Müzesi Yayını, 2019), 160. Resim Bilgisi: Avni Lifij, Manzara, mukavva üzerine yağlıboya, 41,5x 32,5 cm, Sakıp Sabancı Müzesi Koleksiyonu.

58 Kadın sanatçıların otoportre ve diğer çalışmalarının detaylı bilgisi için Ödekan, "İmgenin Dönüşümü,” 56-65; Pelvanoğlu, "Kadın, Eğitim, Sanat," 42-55; Esra Aliçavuşoğlu, "Cumhuriyet Öncesi Dönemden Günümüze Kadın Sanatçıların Kendilerine ve Kadınlara Bakışı,” Sanat Tarihi Yıllı̆̆ XIX (2007), 41-61; Atagök, "Kadın ve Sanat,"16-23; Ahu Antmen ve Esra Aliçavuşoğlu, "Canan Beykal İle Söyleşi Türk Sanatında Kadın ve Kadın Sanatçılar Üzerine,” ST Sanat Tarihi Araştırmaları Dergisi 1, (2006), 135-151 makalelerine bakılabilir. 
açısından önemli bir rol oynamıştır. Bu sergilere basında yer verilir, sergilenen eserler hakkında eleştiri yazıları yazılır. İlki Osmanlı Ressamlar Cemiyeti tarafından 1916'da Beyoğlu Galatasaraylılar Yurdu'nda düzenlenen sergi Türk resim sanatı için önem taşımaktadır. ${ }^{59}$ Bu sergiye kırk dokuz sanatçıdan biri olarak Harika Hanım Salon Dâhili ve Bir çerçeve dâhilinde dört adet Etüt adlı iki yapıtıyla katılır: ${ }^{60}$

Ressamlığının yanı sıra sanat eleştirmeni de olan Avni Lifij, 16 Haziran-13 Ağustos 1916 tarihinde düzenlenen Birinci Galatasaray Sergisi için bir eleştiri yazısı yazar. ${ }^{61}$ Avni Lifij sergiye katılan birçok sanatçının resimleri için düşüncelerini paylaşır ve Harika Hanım'ın çalışmalarını şöyle değerlendirir:

“Sergiye katılan Türk hanımların yapıtları arasında, öncelikle Harika Hanım'ın üstün bir yeteneğe ve eşsiz bir inceliğe işaret eden poşadlarına değinmek istiyorum. Bu genç hanım desene biraz daha dikkat ederse, ileride, onun çok güzel şeyler yapacağına inanıyorum. Bir iç mekânda bir sedirde Okuyan Adam'ı orantılar açısından biraz kusurlu. Kaldı ki, neredeyse sergiye katılan tüm ressamlarda rastlanan bir kusur bu."62

Harika Hanım, 1917 yılında açılan İkinci Galatasaray Sergisi'ne Ahenktar Sesler adlı resmiyle katılır. ${ }^{63}$ Galatasaraylılar Yurdu'nda düzenlenen ikinci serginin ardından yine aynı yerde Aralık 1917'den Ocak 1918 tarihine kadar açık kalan Savaş Resimleri ve Diğerleri sergisi açılır. Harika Hanım da önce Savaş Resimleri ve Diğerleri/ Şişli Atölyesi Resim Sergisi'ne daha sonra Viyana Üniversitesi'nde 1918'de aç1lan Viyana Sergisi'ne Portre, Dekorasyon Taslă̆l, Ilahlar Nezdinde/İlahlar Ĕ̆leniyor (G.3), Ahenk/Armoni (G.4), San Stefano/Yeşilköy'den Manzara (G. 1), Taslak, Selvi Ağacı (G. 5), Sabah isimli çalışmalarla katılır. ${ }^{64}$ Devlet tarafından görevlendirilen Celâl Esad'ın sorumluluğunda 1918'de Viyana'da yirmi sanatçının yüz kırk iki eseri sergilenir. ${ }^{65}$ Ruşen Zamir Hanım' ${ }^{66}{ }^{66}$ birlikte sergiye seçilen iki kadından biri olan Harika Hanım'ın sekiz resmi Viyana'da ilgi çeker. ${ }^{67}$

59 Bu konuda ayrıntılı bilgi için bkz. Resim Tarihimizden: Galatasaray Sergileri 1916-1951. Ed. Ömer Faruk Şerifoğlu (İstanbul: Yapı Kredi Yayınları, 2003).

60 Resim Tarihimizden: Galatasaray Sergileri 1916-1951, 24-25.

61 Avni Lifij'in Birinci Galatasaray Sergisi hakkındaki yazısı İstanbul'da Fransızca yayın yapan Hilal gazetesinde yayımlanmıştır. Avni Lifij Sanat Yazıları, haz. Ömer Faruk Şerifoğlu, İstanbul: Kırmızı Kedi Yayınevi, 2019), 88.

62 Avni Lifij Sanat Yazllarl, 94.

63 Resim Tarihimizden: Galatasaray Sergileri 1916-1951, 26-27.

64 Gören, Türk Resim Sanatında Şişli Atölyesi ve Viyana Sergisi, 52, 99, 100; Mehmet Üstünipek, Tanzimat'tan Cumhuriyet'e Çağdaş Türk Sanatında Sergiler 1850-1950 (İstanbul: Artes Yayınları, 2007), 93-94. Resimlerin sergi kataloğundaki isimleri İlahlar Nezdin, Ahenk, Dekor (eskiz), Ayestefanos (poşad), Poşad, Selvi, Portre, Sabah olarak geçmektedir. Resim Tarihimizden: Galatasaray Sergileri 1916-1951, 26-27.

65 Gören, Türk Resim Sanatında Şişli Atölyesi ve Viyana Sergisi, 52, 57, 83; "Resim Sergisi”, Tasvir-i Efkâr, 31 Kânûn-u Evvel 1333/31 Kânûn-u Evvel 1917.

66 İnas Sanayi-i Nefise öğrenci ve mezunlarının yer aldığ 1 Galatasaray sergilerinde 1916 ve 1917 yıllarında Ruşen Zamir adı geçer ancak daha sonra pek bir varlık gösterememiştir. Nazan Azeri, "Batılılaşma Hareketleri İçinde Kadın Ressamlar”, 67; Ruşen Zamir Hanım hakkında Viyana Sergisi’ne Gökkuşağı resmiyle katıldığı dışında bilgi edinilememiştir. Gören, Türk Resim Sanatında Şişli Atölyesi ve Viyana Sergisi, 121.

67 Gören, Türk Resim Sanatında Şişli Atölyesi ve Viyana Sergisi, 100. 
Avni Lifij, Osmanlı Ressamlar Cemiyeti’nin organize ettiği 1916 Birinci Galatasaray Sergisi, 1917 İkinci Galatasaray Sergisi ve üçüncü olarak Savaş Resimleri ve Diğerleri sergileri için "Sanat ve Tenkit” adlı bir yazı yayımlar. Avni Lifij, iki senede üç sergi diyerek başladığı yazıda Harika Hanım’ın sanatını şöyle değerlendirir: ${ }^{68}$

\begin{abstract}
"Kufi hat ile atılmış Harika imzasını havi resimlere gelelim; mesleğinin en ince güzelliklerini müdrik bir zekâ taşıdığını, en dakik sanat hisleriyle müzeyyen [süslenmiş] bir ruh sahibi olduğunu bu genç hanım eserleriyle ispat ediyor. Onun zarif poşadları, etütleri, eskizleri ne güzel şeylerdir! Hakikat böyle iken o renkli şiirler içinden bir tekini en şedit tenkitlerle, daha doğrusu en lüzumsuz ve manasız kelimelerle ezmeğe kalkmak ve ötekileri, gözü köre bahse değmezmiş gibi telakki etmek, kalakalmak! Bu kadir naşinaslık [bilmezlik] değil midir? Bir sanatkârın müteadit eserleri arasında çekiştirilmeye layık olanları da bulunabilir. Tenkitten kurtulmuş kim ve ne vardır? Fakat öyle bile olsa münekkidin vazifesi o eserleri elekten geçirdikçe hoşa gitmeyecek olanları ayırırken iyi olanlar üzerine de halkın nazar-1 dikkatini celp etmektir. Velhasıl sanatla yirmi senelik iştigalin verdiği salahiyetle söylüyorum ki o hanımın resimleri ile Türk kadınlığı bihakkın iftihar edebilir, o hanım büyük bir istidat sahibi, hassas bir artisttir." ${ }^{99}$
\end{abstract}

Avni Lifij, Harika Hanım'la evlenmeden önce yazdığı yazılarında özellikle poşadlarını beğenir, iftihar edilecek bir Türk kadını olarak yetenekli ve hassas bir sanatçı olarak görür.

Galatasaray Sergileri'nde saltanatın sanatı ve sanatçıyı destekleme yönündeki tavrı, Cumhuriyet'in Birinci Ankara Sergisi'nde de uygulama alanı bulur. Harika Hanım, Cumhuriyetin ilanından on gün önce 19 Ekim 1923'te Ankara'da Türk Ocağı binasında açılan ilk resim sergisine de katılır. Birinci Ankara Sergisi'nin açı1ışı Hakimiyet-i Milliye'de iki gün boyunca birinci sayfadan duyurulur. Yazıda bahsedilen sergiye katılan bazı isimler arasında Harika Hanım da bulunmaktadır:

“(...) Ressamlarımızın ismi -hurûf-1 hece sırasıyla şunlardır: İnas Sanayi-i Nefise Mektebi'nden İhsan ve Efraz Hanımlar, İstanbul sanayi-i nefise mektebinden mezun Ahmed Ziya Bey, İstanbul ve Paris sanayi-i nefise mekteblerinden mezun Çallı İbrahim Bey, Serbest Resim Atölyesi sahib ve müdürü İhsan Efendi, İstanbul ve Paris sanayi-i nefise mekteblerinden Belkıs Hanım, İstanbul sanayi-i nefisesinden Bakıye ve Bedia hanımlar, Cevad Bey, İstanbul ve Paris sanayi-i Nefiselerinden mezun Hikmet Bey, Paris sanayi-i nefisesinden mezun Halil Paşa, İstanbul ve Paris’ten mezun Ruhi ve Sami Beyler, Said Bey, İstanbul sanayi-i nefisesinden mezun Şevket Bey, ressam Ruhi Bey’in talebesi Şemseddin Ruhi Bey, Medresetü'l-Hattatîn müzehhib muallimi Tahir Bey, Paris

68 Küpür hâlinde bulunan bu yazının nerede ve ne zaman yayımlandığı tespit edilememiştir. Avni Lifij Sanat Yazıları. Haz. Ömer Faruk Şerifoğlu (İstanbul: Kırmızı Kedi Yayınevi, 2019), 95.

69 Avni Lifij Sanat Yazıları, 98-100. 
sanayi-i nefisesinden mezun Avni Bey Lifij ve refikaları Harika Avni Hanım, Roma sanayi-i nefisesinden mezun Ömer Adil Bey.” 70

1923 y1lında Ankara Sergisi’nde Harika Hanım'ın Ramazan Gecesi (G. 7) isimli eseri sergilenir ve sergi yazısında övülmeye layık yapıtlar arasında gösterilir. ${ }^{11} 1924$ 'te Ankara'da Milli Sanayi-i Nefise Cemiyeti adıyla yeni bir oluşum kurulur. Aynı yıl Milli Sanayi-i Nefise Cemiyeti ve Serbest Resim Atölyesi tarafindan Muallimler Birliği binasında düzenlenen Ankara Sanayi-i Nefise Meşheri’nde on beş sanatçının yüz kırk sekiz eseri sergilenir. Harika Hanım da bu sergiye dört eseri ile katılır. ${ }^{72}$ Avni Lifij bu sergi için "Mukavvat Bediiyat Mektepleri” başlıklı bir yazı kaleme alır ve bu yazıda "Harika Avni Lifij, zevcem olduğu için resimlerinden bahsetmek bana düşmez" diyerek yorumsuz kalır ama Harika Hanım’ın sergideki varlığını işaret eder.

Harika Hanım 1949 yılında İstanbul Sanat Dostları Cemiyeti Galerisi’nde Kadın Ressamlar Sergisine katılır. ${ }^{74} 1957$ yılında resim yapmayı bırakır. Canan Beykal, Harika Hanım'ı hayatını eşiyle doldurmak ve onun için yaşamını anlamlı kılmak istemiş sanatçılardan biri olarak tanımlar. ${ }^{75}$ Kendi resimlerine Avni Lifij' in resimleri kadar özen göstermediğinden elli kadar eseri günümüze ulaşmıştır. Bu resimler yeğenlerinde ve çeşitli özel koleksiyonlarda yer almaktadır.

Harika Hanım dönemin sergi yazılarında genellikle Avni Bey’in refikası (eşi) olarak yer alır. Daha sonra yayımlanan kitaplarda da Avni Lifij' in eşi olarak anılmaya devam eder. Asker kökenli ressam Pertev Boyar'ın (1897-1981) Osmanlı Imparatorluğu ve Türkiye Cumhuriyeti Devirlerinde Türk Ressamları (1948) kitabı buna örnektir. Bu kitap aslında bir ansiklopedidir ve hem listesiyle hem verileriyle sanat tarihiyle ilgili araştırmalara kaynaklık eder. Boyar'ın kitabında sivil ressamlar bölümünde seksen sekiz ressamdan on biri kadındır. Harika Hanım bu listenin içerisinde yer almaktadır. ${ }^{76}$

Feminist kuramcı ve sanat tarihçisi Griselda Pollock, 1987 yılında yayımlanan Kadın, Sanat ve İdeoloji: Feminist Sanat Tarihçileri İçin Sorular başlıklı makalesinde

70 Haberi 20 Ekim 1923 tarihli Hâkimiyet-i Milliye’den aktaran Ömer Faruk Şerifoğlu, “1923 Birinci Ankara Resim Sergisi: Cumhuriyet'in İlanı ve Yeni İdealler,” Sanat Dünyamız 156 (İstanbul: Yapı Kredi Yayınları, 2017), 49-50.

71 “Resim Sergisi”, Hakimiyet-i Milliye, 15 Teşrin-i Evvel 1923; Özyiğit, "1920-1928 Yılları Arasında Süreli Yayınlarda Kültür ve Sanat Yorumları: Resim,” 290.

72 Milli Sanayi-i Nefise Cemiyeti’nin kurucuları, Çamlıca Lisesi resim muallim-î sâbıkı Üstad Ali Rıza Bey, Mütekaidin-i Bahriye'den kaymakam Ressam İsmail Hakkı Bey, Avni Lifij, Evkaf Müzesi Müdürü Ressam Ali Sami Bey ile Serbest Resim Atölyesi sahip ve müdürü Ressam İhsan Ahmed Bey’dir. Avni Lifij Sanat Yazllarl, 42-44.

73 Avni Lifij Sanat Yazlarl, 162.

74 Zehra Canan Bayer, “Cumhuriyet Dönemi (1923-1950) Türk Ressamlarının Türk Resim Sanatının Gelişsimine Yazıları İle Katkıları” (Doktora Tezi, Mimar Sinan Güzel Sanatlar Üniversitesi, 2009), 420.

75 Antmen ve Aliçavuşoğlu, "Canan Beykal İle Söyleşi Türk Sanatında Kadın ve Kadın Sanatçılar Üzerine," 144-145.

76 Ahu Antmen, “Bu Bayan Ressam... Sanat Tarihinde Dışlama Senaryoları,” Sanatın Gölgedeki Kadınları, der. Özlem Belkıs ve Duygu Kankaytsın (İstanbul: Ayrıntı Yayınları, 2018), 98. 
şöyle yazar: “... [sanat tarihi disiplini] çalıştıkları, öğrettikleri, eledikleri ya da marjinalize ettikleri aracılığıyla ve tarihin, sanatın ve de sanatçının kim veya ne olduğunu tanımlama şekliyle kültürel hegemonyanın egemen toplumsal ilişkileri devam ettiren ve yeniden üreten bir bileşenidir." " 77 Pollock'un Batı sanat tarihi ve sanat yazımı için dile getirdiği şeyler Türk sanatı için de geçerlidir. Sanat tarihi literatüründe sanatçılardan bahsedilirken hep sanatçı ve kadın sanatçı ayrımı yapılır. Diğer kadın sanatçılar gibi Harika Hanım da bundan payını alır. Kendisinden çok kısa bahsedilir veya genel olarak kadın ressamlar içerisinde gösterilerek sanatı ve yaşamı kısaca aktarılır. Eserleri hakkındaki en uzun eleştiri ve yorum, eşi olmadan önce Avni Lifij tarafından ve kadın sanatçı olduğu vurgulanmadan yapılmıştır.

Avni Lifij'i 1927 yılında kaybettikten sonra resim çalışmalarını ikinci plana atar ve kendisini eşinin adını ve resimlerini yaşatmaya adar. Bu arada etüt resim çalışmalarına devam etse de 1957 yılından sonra resim yapmayı tamamen birakır. Numune okullarında öğretmenliğe devam eden Harika Lifij, 1951 yılında 37 y1l boyunca severek yaptığı öğretmenlikten emekliliğini ister. ${ }^{78}$ Son yıllarında, Sanat Çevresi, Hayat Tarih ve Edebiyat, Ankara Sanat gibi çeşitli sanat dergilerine anılarını yazar. Doksan beş yıllık yaşantısına ressamlığı, resim öğretmenliğini ve Avni Lifij' in çalışmalarını korumayı sığdıran Harika Hanım, 1991 yılında vefat eder ve Avni Lifij'in Piyer Loti Kahvesi'nin hemen yanındaki mezarına defnedilir.

\section{Sonuç}

Makalede Harika Lifij' in 1912-1924 yılları arasındaki resimleri ve katıldığı sergiler incelenmiştir. Harika Lifij, yakın çalışma arkadaşı olan eşinden ve hocası Müfide Kadri'den etkilenmişse de kendi resim dilini oluşturmuş bir sanatçıdır. Açık havada resim yapmayı sever. Yağlıboya tekniğiyle çalışan sanatçının poşadları adeta İstanbul'un şiirsel havaya bürünmüş köşeleri gibidir. Harika Hanım'ın Avni Lifij'le evlenmeden önce de romantik, alegorik ve mitolojik resimler yaptığı düşünülürse etkileşimin karşılıklı olduğu tahmin edilebilir.

Galatasaray Sergileri'ne 1918'den sonra katılmayan, Ankara'daki sergilerde de 1924 'ten sonra ismine rastlanmayan Harika Hanım'ın resimlerinin sayısının azlığı, tekniği ve sanatı hakkında değerlendirme yapmayı kısıtlasa da bu resimlerde konu çeşitliliği dikkat çekmektedir. Bu resimler tür resmi olarak gündelik yaşamdan, mitolojik ve alegorik resimlere, poşadlardan otoportreye geniş bir yelpaze sunmaktadır.

77 Griselda Pollock, "Women, Art, and Ideology: Questions for Feminist Art Historians," Women's Studies Quarterly, Teaching about Women and the Visual Art, vol. 15, no. 1/2 (Spring-Summer 1987), 2. erişim 15 May1s 2020. https://edisciplinas.usp.br/pluginfile.php/5062306/mod_resource/content $/ 1 /$ Griselda $\% 20$ Pollock $\% 20$ Feminist\%20Art\%20History\%201987.pdf

78 Harika Sirel Lifij' in Yaşamı, 33. 
Viyana Sergisi Avrupa'da Türk ressamları tarafından açılan ilk sergi olması ve sergiye seçilen iki kadın sanatçıdan birinin Harika Hanım olması önemlidir. Ruşen Zamir Hanım'ın tek eserinin sergilenirken, Harika Hanım'ın sekiz resminin sergilenmesi kariyeri açısından büyük bir başarıdır. Ilahlar Ĕgleniyor (G. 3) ve Ahenk) Armoni (G. 4) resimlerinin Viyana Sergisi’nde sergilendiği bilinirken sergilenen diğer iki resminin Yeşilköy'den Manzara/Ayastefanos (G. 1), Sarı Bina Önündeki Sokak/ Selvi A ğacı (G. 5) resimleri olduğu tespit edilmiştir. Genç yaşında mitolojik konularla ilgilenmesi, Savaş Resimleri Sergisi bağlamında hazırladığı iki resmin savaş yerine sevgiyi ve barışı vurgulaması dikkat çeker. Ilahlar Ĕgleniyor resmiyle savaşla alay etmesi, Ahenk/Armoni resmiyle de savaşa giren bir toplumda savaş sonrasında büyük dayanışmayı ve sevgiyi sembolize etmesi zekasına ve duygusal yönüne vurgu yapar. $\mathrm{Ne}$ de olsa her sanatçı eserlerinde kişiliğinden izler taşır. 1914 tarihli Otoportre'si (G. 2) Meşrutiyet kadını olarak kendini görünür kılmasının ve var olma çabasının bir sonucudur. Fatih Camii/Ramazan Gecesi (G. 7) A ğaçlı Sokak ve Sarı Bina (G. 8) resimlerinde tür resmi olarak gündelik yaşam içerisindeki sokaktaki insanları ve değişen yaşam tarzını gösterir.

Harika Hanım, eşinin fırçasındaki gibi naif, duygusal, yazılarında belirttiği gibi yetenekli, iftihar edilecek bir Türk kadını, 1912-1924 yılları arasında resimleri ile sanat dünyasının içinde yer alan hassas bir sanatçı, kendini eşinin eserlerini ve adını yaşatmaya adayan bir eş ve yeni öğrenciler yetiştiren bir öğretmen olarak Türk sanat tarihi içinde yer alır.

Hakem Değerlendirmesi: Dış bağımsız.

Çıkar Çatışması: Yazar çıkar çatışması bildirmemiştir.

Finansal Destek: Yazar bu çalışma için finansal destek almadığını beyan etmiştir.

Teşekkür: Bu çalışmanın hazırlanma sürecinde Prof. Şazi Sirel-Ayten Sirel Arşivi’nde bulunan Harika Sirel Lifij'in Yaşamı'nı benimle paylaşan Ömer Faruk Şerifoğlu'na içtenlikle teşekkür ediyorum.

Peer-review: Externally peer-reviewed.

Conflict of Interest: The author has no conflict of interest to declare.

Grant Support: The author declared that this study has received no financial support.

Acknowledgement: I sincerely thank Ömer Faruk Şerifoğlu, who shared the Life of the wonderful Sirel Lifij in the Prof Şazi Sirel-Ayten Sirel Archive during the preparation of this study.

\section{Kaynakça/References}

Akagündüz, Ümüt. II. Meşrutiyet Döneminde Kadın Olmak. İstanbul: Yeni İnsan Yayınevi, 2015. Aksel, Malik. Sanat ve Folklor. Haz. Beşir Ayvazoğlu. İstanbul: Kapı Yayınları, 2011.

Aliçavuşoğlu, Esra. "Cumhuriyet Öncesi Dönemden Günümüze Kadın Sanatçıların Kendilerine ve Kadınlara Bakış1.” Sanat Tarihi Yıllığı XIX. (2007): 41-61.

Antmen, Ahu ve Esra Aliçavuşoğlu. "Canan Beykal İle Söyleşi Türk Sanatında Kadın ve Kadın

Sanatçılar Üzerine.” ST Sanat Tarihi Araştırmaları Dergisi 1, (2006):135-151.

Antmen, Ahu. Kimlikli Bedenler Sanat, Kimlik, Cinsiyet. İstanbul: Sel Yayınc1lık, 2013. 
Antmen, Ahu. "Bu Bayan Ressam... Sanat Tarihinde Dışlama Senaryoları.” Sanatın Gölgedeki Kadınları. Der. Özlem Belkıs ve Duygu Kankaytsın. İstanbul: Ayrıntı Yayınları, 2018.

Atagök, Tomur. "Kadın ve Sanat," Cumhuriyet'ten Günümüze Kadın Sanatçılar, Çağlarboyu Anadolu'da Kadın Sergileri. İstanbul: TC. Kültür Bakanlığı Anıtlar ve Müzeler Genel Müdürlüğü, 1993, 16-23.

Avni Lifij Sanat Yazıları. Haz. Ömer Faruk Şerifoğlu, İstanbul: Kırmızı Kedi Yayınevi, 2019.

Aydın, Derya Uzun. "Cumhuriyet Dönemine Işık Tutan İki Heykeltıraş; Mahir Tomruk ve Ali Nijat Sirel.” İstanbul Sosyal Bilimler Dergisi 3 (2013): 1-17. Erişim 27 Nisan 2020. http://www.istjss. org/resim/2013_spring_3_1.pdf

Azeri, Nazan. "Batılılaşma Hareketleri İçinde Kadın Ressamlar.” Yüksek Lisans Tezi, Marmara Üniversitesi, 1996.

Bayer, Zehra Canan. "Cumhuriyet Dönemi (1923-1950) Türk Ressamlarının Türk Resim Sanatının Gelişimine Yazıları İle Katkıları.” Doktora Tezi, Mimar Sinan Güzel Sanatlar Üniversitesi, 2009.

Berktay, Fatmagül. "Hayal ve Hakikat ya da Hayalin Hakikatine Bitmeyen Yolculuk," Hayal ve Hakikat: Türkiye'den Modern ve Çağdaş Kadın Sanatçılar/Dream and Reality: Modern and Contemporary Women Artists from Turkey. Ed. Esin Eşkinat. İstanbul: Modern Sanat Müzesi, 2011, 26-41.

Beykal, Canan. "Yeni Kadın ve İnas Sanayi-i Nefise Mektebi." Boyut 16 (1983): 6-13.

Cumhuriyeti Karşılayan Kadın Ressamlar Kataloğu. İstanbul: KÜSAV, 1998.

Çakır, Serpil. Osmanlı Kadın Hareketi. İstanbul: Metis Yayınları, 1996.

Gören, Ahmet Kamil. "Kısa Yaşamının Büyük Mirasıyla Avni Lifij.” Avni Lifij Çağının Yenisi. İstanbul: Sabancı Üniversitesi Sakıp Sabancı Müzesi Yayını (15 Ekim 2019-12 Ocak 2020 Avni Lifij, Çağının Yenisi Sergi Kataloğu), 2019, 30-41.

Gören, Ahmet Kamil. "Özgür Bir İfadenin Sonucu Olarak Ressamın Kendi Sureti: Otoportre," Nurhan Atasoy'a Armağan. Ed. M. Baha Tanman. İstanbul: Lale Yayıncılık Kültür ve Sanat Yayınlar1-1, [Haziran] 2014, 173-184.

Gören, Ahmet Kamil. “Türk Resminin Önemli Bir Odağı: Saray Koleksiyonu.” İhtişam ve Tevazu Padişahın Ressam Kulları. İstanbul: TBMM Milli Saraylar Yayını, 2012, 15-40.

Gören, Ahmet Kamil. Avni Lifij. İstanbul: Yapı Kredi Yayınları, 2001.

Gören, Ahmet Kamil. Türk Resim Sanatında Şişli Atölyesi ve Viyana Sergisi. İstanbul: Şişli Belediyesi, 1997.

Gören, Ahmet Kamil. “Türkiye'de Güzel Sanatlar Okulları: 2, İnas Sanayi-i Nefise Mektebi, Kadın Ressamlar, Özel Resim Atölyesi ve Resim Kurslar1.” Türkiyemiz Kültür ve Sanat Dergisi 82 (Kasım 1997): 12-27.

Graves, Robert. Yunan Mitleri, Tanrllar, Kahramanlar, Söylenceler. Çev. Uğur Akpur. İstanbul: Say Yayınları, 2012.

Harika Sirel Lifij’ in Yaşamı. Prof. Şazi Sirel-Ayten Sirel Arşivi.

Lifij, Harika Sirel. "Eşim Avni Lifij ve Ben...”. Sanat Çevresi 45 (Temmuz 1982): 16-17.

Lifij, Harika. “Öğretmen Hârika Lifij' in Hatırladıkları.” Hayat Tarih ve Edebiyat 7 (Temmuz 1981): 14-16.

"Numune Mektepleri (Örnek okullar).” Erişim 14 Nisan 2020. http://www.istanbulkadinmuzesi. org/numune-mektepleri 
Okkalı, İlkay Canan. "II. Meşrutiyet Dönemi Resim Sanatında Nesne ve Özne Olarak Kadın.” Art-Sanat 11 (Ocak 2019): 47-70. Erişim 27 Nisan 2020. https://doi.org./10.26650/artsanat.2019.11.0003

Okkalı, İlkay Canan. "Güzin Duran: Eşinin Gölgesinde Bir Kadın Ressam.” Sanatın Gölgedeki Kadınları. Der. Özlem Belkıs ve Duygu Kankaytsın. İstanbul: Ayrıntı Yayınları, 2018, 444-456.

Ödekan, Ayla. "İmgenin Dönüşümü/The Transformation of The Image," Hayal ve Hakikat: Türkiye'den Modern ve Çağdaş Kadın Sanatçılar/Dream and Reality: Modern and Contemporary Women Artists from Turkey. Ed. Esin Eşkinat. İstanbul: İstanbul Modern Sanat Müzesi, 2011, 56-65.

Özyiğit, Halil. “1920-1928 Yılları Arasında Süreli Yayınlarda Kültür ve Sanat Yorumları: Resim.” Yüksek Lisans Tezi, Pamukkale Üniversitesi, 2005.

Pelvanoğlu, Burcu. “Kadın, Eğitim, Sanat.” Hayal ve Hakikat: Türkiye’den Modern ve Çă̆daş Kadın Sanatçılar/Dream and Reality: Modern and Contemporary Women Artists from Turkey. Ed. Esin Eşkinat. İstanbul: İstanbul Modern Sanat Müzesi, 2011, 42-55.

Pelvanoğlu, Burcu. Hale Asaf-Türk Resim Sanatında Bir Dönüm Noktası. İstanbul: Yap1 Kredi Yayınları, 2007.

Pollock, Griselda. "Women, Art, and Ideology: Questions for Feminist Art Historians," Women's Studies Quarterly, Teaching about Women and the Visual Art, vol. 15, no. 1/2, (Spring-Summer 1987): 2-9.

Renda, Günsel. “Osmanlılarda Heykel.” Sanat Dünyamız 82 (Kış 2002): 138-145.

"Resim Sergisi." Hâkimiyet-i Milliye, 20 Ekim 1923.

"Resim Sergisi.” Hakimiyet-i Milliye, 15 Teşrin-i Evvel 1923.

“Resim Sergisi.” Tasvir-i Efkâr, 31 Kânûn-u Evvel 1333/31 Kânûn-u Evvel 1917.

Resim Tarihimizden: Galatasaray Sergileri 1916-1951. Ed. Ömer Faruk Şerifoğlu. İstanbul: Yap1 Kredi Yayınları, 2003.

Şerifoğlu, Ömer Faruk. "1923 Birinci Ankara Resim Sergisi: Cumhuriyet'in İlanı ve Yeni İdealler.” Sanat Dünyamız 156 (Ocak-Şubat 2017): 42-63.

Toros, Taha. İlk Kadın Ressamlarımız. İstanbul Ak Yayınları Sanat Kitapları Serisi: 12-1, 1988.

Tunç, Uğurgül. “Osmanlı Modernleşmesinde Eğitim, Sanat ve Kadın: İnas Sanayi-i Nefise Mekteb-i Âlisi Örneği.” Yüksek Lisans Tezi, İstanbul Teknik Üniversitesi, 2018.

Ürekli, Fatma. "Güzel Sanatlar Eğitiminde Osmanlı Hanımlarına Açılan Bir Pencere, İnas Sanayi-i Nefise Mektebi." Tarih ve Toplum Dergisi 231 (Mart 2003): 50-60.

Üstünipek, Mehmet. Tanzimat'tan Cumhuriyet'e Çağdaş Türk Sanatında Sergiler 1850-1950. İstanbul: Artes Yayınları, 2007.

Yaman, Zeynep Yasa. “İnas Sanayi-i Nefise Mektebi Âlisi.” Dünden Bugüne İstanbul Ansiklopedisi. c. IV. İstanbul: İletişim Yayınları, 1994, 170-171. 